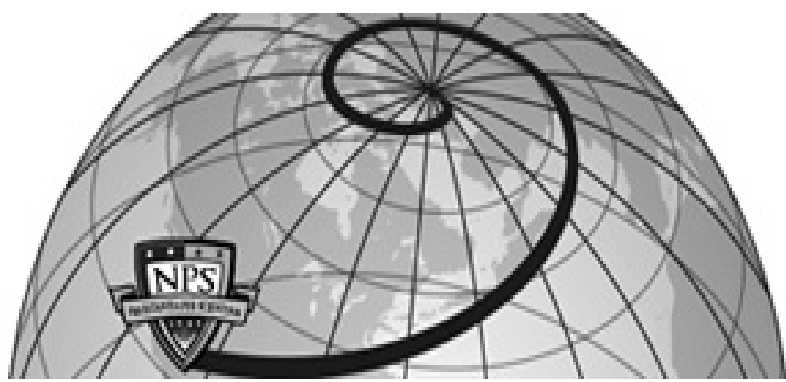

Calhoun: The NPS Institutional Archive DSpace Repository

\title{
Construction contract durations
}

Thornton, Michael D.

http://hdl.handle.net/10945/22987

Downloaded from NPS Archive: Calhoun



http://www.nps.edu/library
Calhoun is the Naval Postgraduate School's public access digital repository for research materials and institutional publications created by the NPS community. Calhoun is named for Professor of Mathematics Guy K. Calhoun, NPS's first appointed -- and published -- scholarly author.

Dudley Knox Library / Naval Postgraduate School 411 Dyer Road / 1 University Circle Monterey, California USA 93943 


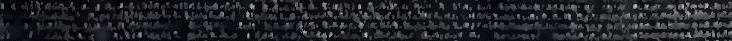

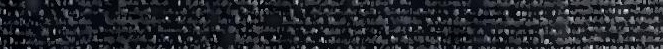
(4)

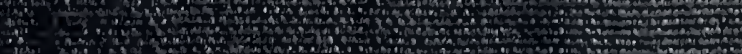
1
4

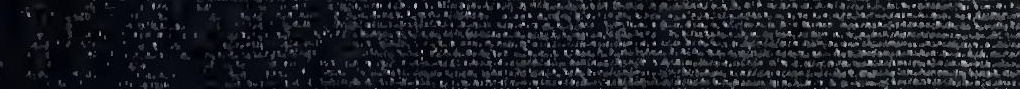

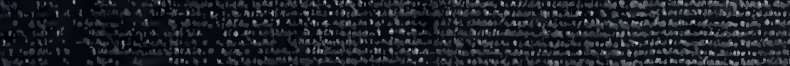
and

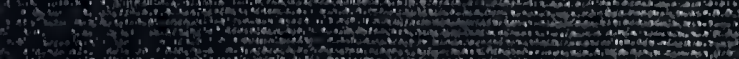

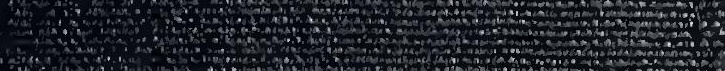

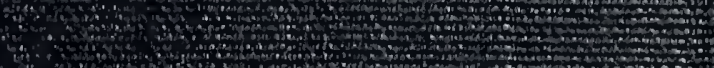

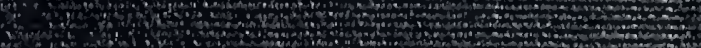



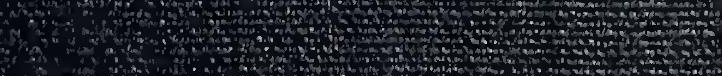
(3) W W

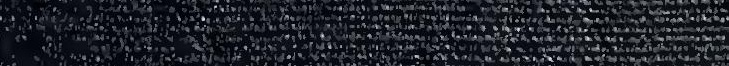
(15) (3) a d Hat n (n) (3)

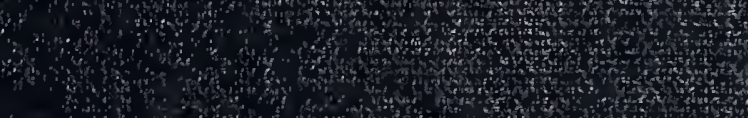
4. a.

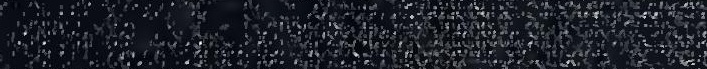

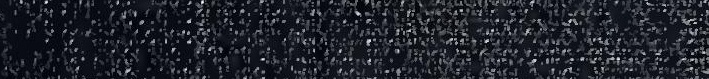

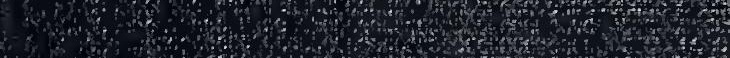

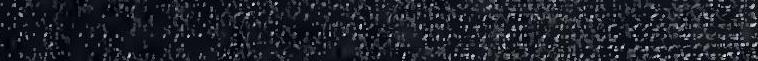

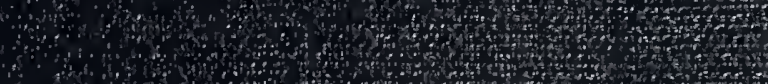

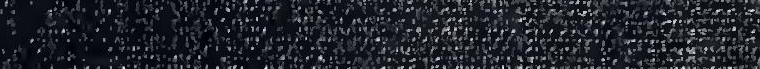

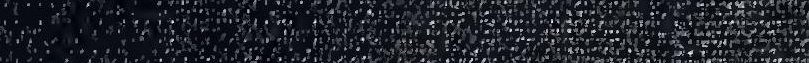

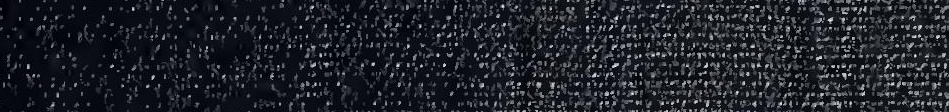

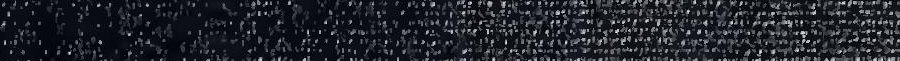

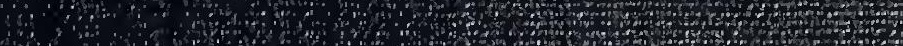
W and

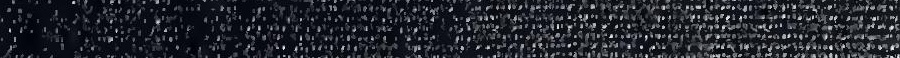

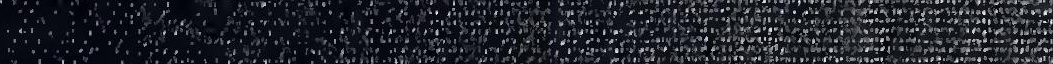
(n) and


and and

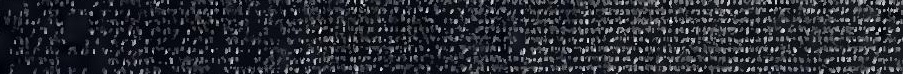
H.t.

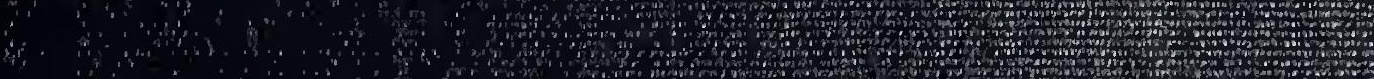
A 




\section{Construction Contract Durations}

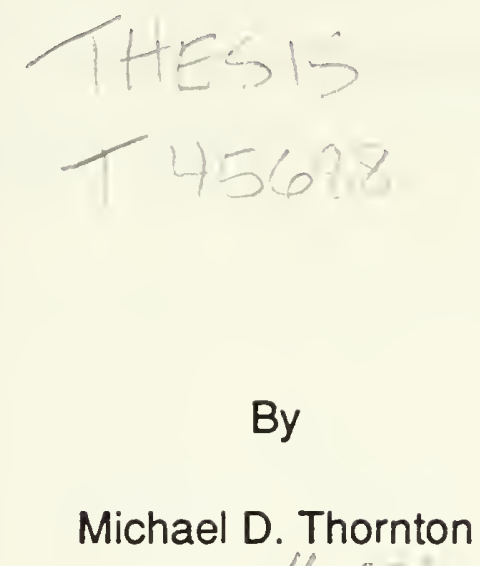

A REPORT PRESENTED TO THE GRADUATE COMMITTEE OF THE DEPARTMENT OF CIVIL ENGINEERING IN PARTIAL FULFILLMENT OF THE REQUIREMENTS FOR THE DEGREE MASTER OF SCIENCE

University of Florida

Spring 1988 
Thes: 7. $6: 8$

.1 
I want to dedicate this report to my wife, DeAnne, who has for the past 21 months supported me with love, kindness, and understanding. Knowledge is a great thing and I am grateful for the opportunity to seek it. However, I must forever be indebted to my wife and family for their support in making this degree a reality. 



\section{Abstract}

This report examines the factors which affect construction contract durations from an owner's viewpoint. Current methods used by public owners and their agents to develop contract durations are also examined. The major hypothesis is that there exists an optimum contract duration for which the owner receives an optimum price. If the facility is desired in less than the optimum duration, the owner pays a premium for acceleration. If the owner allows the contractor more than the optimum duration, he pays additional costs for the facility in terms of lost revenue, denial of use of the facility, and possibly additional costs to the contractor. The report offers conclusions so that owners can understand the tradeoffs between time and price. 

Table of Contents

List of Figures

Chapter One Introduction

1.1 Importance of Contract Duration 1

1.2 Definition of Contract Duration 4

1.3 Starting Point 5

1.4 Stopping Point $\quad 7$

1.5 Legal Significance of Contract Duration 7

1.6 Project Schedules 8

1.7 Optimum Contract Duration 9

Chapter Two Factors Which Effect Duration 11

2.1 Introduction 11

2.2 Size of the Project 12

2.3 Type of the Project 14

2.3.1 Residential 15

2.3.2 Building Construction 17

2.3.3 Industrial 17

2.3.4 Engineering Construction 18

2.4 Type of Construction 19

2.4.1 New Construction 20

2.4.2 Renovation 20

2.4.3 Horizontal 21

2.4.4 Vertical 22

2.5 Type of Material 23

2.6 Type of Contract 26

2.6.1 Lump Sum 31

2.6.2 Unit Price 32

2.6.3 Cost Reimbursable 32

2.6.4 The Convertible Contract 35

2.7 Local Conditions 36

2.8 Administrative Requirements 36

$\begin{array}{ll}2.9 \text { Other Factors } & 39\end{array}$ 

2.10 Delivery Systems

2.10.1 Construction Management $\quad 40$

2.10.2 Design-Construct 42

2.11 Conclusions

Chapter Three Discussion of Methods

3.1 Introduction 44

3.2 CPM to Determine Duration $\quad 45$

3.3 Production Rates 48

3.4 Parameters 50

3.5 Engineering Judgement 52

Chapter Four Current Methods Used by Agencies 54

4.1 Introduction 54

4.2 Federal Acquisition Regulations 55

4.3 U.S. Naval Facilities Engineering Command 56

4.4 Corps of Engineers 62

4.5 State Department of Transportation 65

4.5.1 Idaho DOT 70

4.5.2 Mississippi DOT 73

4.6 Competition for Delivery $\quad 73$

4.7 City of Gainesville $\quad 76$

$\begin{array}{ll}4.8 & \text { Design Firms }\end{array}$

Chapter Five Some Thoughts on Contract Durations $\quad 79$

5.1 Why No Analysis? $\quad 79$

5.2 Too Many Factors $\quad 80$

5.3 Measurement of Success 82

5.4 Future Contracts 83

Chapter Six Summary and Conclusions $\quad 85$

$\begin{array}{ll}6.1 \text { Summary } & 85\end{array}$

6.2 Conclusions $\quad 87$ 



\section{List of Figures}

1. Graph of Relationship between Contract Time and Cost

2. Relative Effectiveness in Achieving Owners Goals

3. Summary of Contract Types

4. Graph of Project Schedule Duration Versus Contract Type

5. Summary of State DOT Duration Methods

6. Idaho DOT Graph for Determining Contract Duration

7. Graph of Relationship between Time, Cost, and Quality 



\section{CHAPTER ONE \\ INTRODUCTION}

\subsection{Impertance of Contract Duration}

Two items that are common among nearly all construction contracts are time and money. With each item, the essence of the contract can be defined. For a specified sum of money, a contractor will be required to perform within the specified period of time. Most owners are well adept at evaluating bids based on money. However, owners generally have little understanding of the duration necessary to perform the work for which they are contracting. Contract time can be considered the neglected step-child of the contracting world. It is unfortunate that the duration is often set with no real relationship to the work required. To be sure, most contracts specifically state that the contract duration is a specified number of days, either calendar or workdays. However, the determination of the amount of time given to the contractor is rarely understood by the makers of the contract. What makes this important to owners is the extra cost they might incur. 

Time is simply money to everyone. Nearly all in construction have felt the effects of that statement in one way or another. Yet most owners continue to make contracts without understanding the time they are allowing for in the contract. This report will examine construction contract durations from an owner's viewpoint, the factors which effect contract durations, and the current methods being used in the industry to determine the pre-award contract durations. It must be noted that this is different from planning and scheduling. Many texts have been written about the importance of planning and scheduling of construction contracts. Many construction professionals, both contractors and engineers, are currently providing professional services as construction managers and planners. They are involved in all phases of the facility from design and estimating through completion of the construction. However, few offer an analysis of the contract to determine the optimum contract duration. This report is concerned with the contract duration that is advertised in the Invitation for Bids or Public Notice. It must also be noted that the contract duration is often considered as one of the items a contractor should consider when making his bid. While planning and scheduling is 

often performed by those responsible for the satisfactory completion of the contract, contract duration is a decision for the owner. Many of the techniques used in planning and scheduling can be applied to determining contract durations. In contrast, planning and scheduling can be considered as the contractor's responsibility for the successful completion of the contract.

A survey of the available literature on construction contract administration, construction management, specifications, and planning and scheduling mention contract durations as something stated in the contract. None mention how contract durations are determined. Some references mention that in order to have the time limit enforced with the hope of defaulting the contractor, the owner must include statements which make "time of the essence". This makes time a material part of the contract rather than an immaterial part. The importance of including statements which make "time of the essence" is derived from the reasoning that if an owner includes liquidated damages in the contract, (which is normally done on public contracts) then the makers are contemplating late 

completion and have established a mechanism (liquidated damages) which will satisfy the apparent breach of contract. However, this does nothing to establish the determination of the contract duration or explain the current methods used by industry to establish contract duration.

\subsection{Definition of Contract Duration}

For the purposes of this report, contract time and contract duration are used interchangeably. This is not meant to confuse the reader.

Contract duration can simply be considered as the time agreed upon by the makers in order to complete the terms of the contract. While this sounds simple, many lawsuits have been filed over the interpretation of contract durations. Most often the lawsuits rise out of the confusion of when contract time starts. As stated earlier, contract time is usually defined as a specified number of calendar days indicated in the Invitation for Bids (federal government) or the Public Notice for Bids (city, state, and private projects). This is by far the most popular method of indicating the duration for a lump sum contract. Two choices are available to 

indicate contract time, either calendar or working days. If working days are used in the contract terms, then the appropriate definition of a working day must also be included. This definition should also be in agreement with any local area labor agreements under its jurisdiction.

Since calendar days relieves this responsibility, it is the easiest to calculate and most public owners use it to indicate the contract duration. Other methods include a predetermined completion date, stated as a calendar date or some other method agreed upon by the parties.

Since most of the construction projects are performed under fixed price, the majority of this report will be framed around that type of contract for analysis. In Chapter Two, other contracting methods will be examined to understand their effect on contract time.

\subsection{Starting Point}

There are several methods used by the industry to start the contract time "running". Three of the most prevalent ones will be considered here.

They are: 1) signing the agreement, 2), issuance of the Notice To Proceed 

(NTP), and issuance of a notice of Award letter. All three methods require the owner to accept the offer from the contractor. Whatever method is used to start the performance period, the contractor needs to be specifically notified that he is expected to begin actual work within a stated number of days (usually 15 to 30 ). This time period, granted at the start of the contract, allows the contractor to mobilize his assets. This entails the movement of men, materials, and equipment onto the job site to begin the work. Another beginning point could be the pre-construction conference. This is a meeting of the owner and the contractor plus other interested parties to the construction contract at which time the details of the contract administration are discussed. A multitude of items are generally discussed, ranging from safety and quality control to site availability and payment procedures. It is important to note in the agreement when the contract time will begin, whatever the mechanism used to start the contract clock running. 



\subsection{Stopping Point}

In the previous paragraphs, the beginning of the contract duration was examined. Of equal importance, the stopping point must also be considered. Generally, the courts have accepted the concept of substantial completion as the ending of the contract. This means that the contractor has accomplished all of the things essential to fulfillment of the contract.

This is peculiar to construction contracts generally and has been developed by the courts as a way of mitigating the severity of exact performance. Also tied to substantial completion is the ending of assessment of liquidated damages (if incurred).

\subsection{Legal Significance of Contract Duration}

Not only money is involved in the completion of the contract. The legal remedy for late completion is also tied to substantial completion and ultimately the duration stated in the contract. It would be a viable defense by the contractor if the duration given in the contract was shown not to be logical considering the work required. This would obviously be 

strengthen by the contractor if he has diligently complied with the other terms of the contract. Therefore, contract time has a great impact on the both parties.

\subsection{Project Schedules}

The term "project schedule" has many meanings depending on the viewpoint of the person using it. Architects, contractors, suppliers, and owners all place a different definition on this term. It can mean the contractual stated final completion date or interim completion dates for phased work. The term often refers to the scheduling of the various items of the work usually done by those in the construction phase of the contract. Most industry people illustrate a project schedule in one of two forms, either the Bar Chart (Gantt) or the Critical Path Method Network (CPM). While this report is not an examination of either method, it is important to note the use of both techniques as to their influence on the contract duration. 



\section{7 eptimum Contract Duration}

Each contract represents a unique set of circumstances. Given the conditions of the contract, bidders evaluate their performance in terms of cost. Bidders also take into account the amount of time required to perform the work requested. Bidders arrive at their price for the contract as stated. However, if an owner changes these circumstances, the price is likely to change also. Following that logic, then there exists an optimum contract duration for the stated conditions. Figure $1^{1}$ illustrates this point. If an owner wants his facility earlier than the optimum, he will pay an additional cost in terms of a premium for earlier delivery. If the contractor is allowed to take longer than the optimum, then the owner pays additional cost in the form of denial of the use of the facility (any lost revenues), increased indirect costs, and escalation. Therefore, it is to his advantage to evaluate the proposed contract for the optimum duration prior to letting it out to bid. With that in mind, it is important to analyze the factors which affect the initial selection of the contract duration. 



\section{Figure 1}

\section{Relationship Between Project Cost and Time}

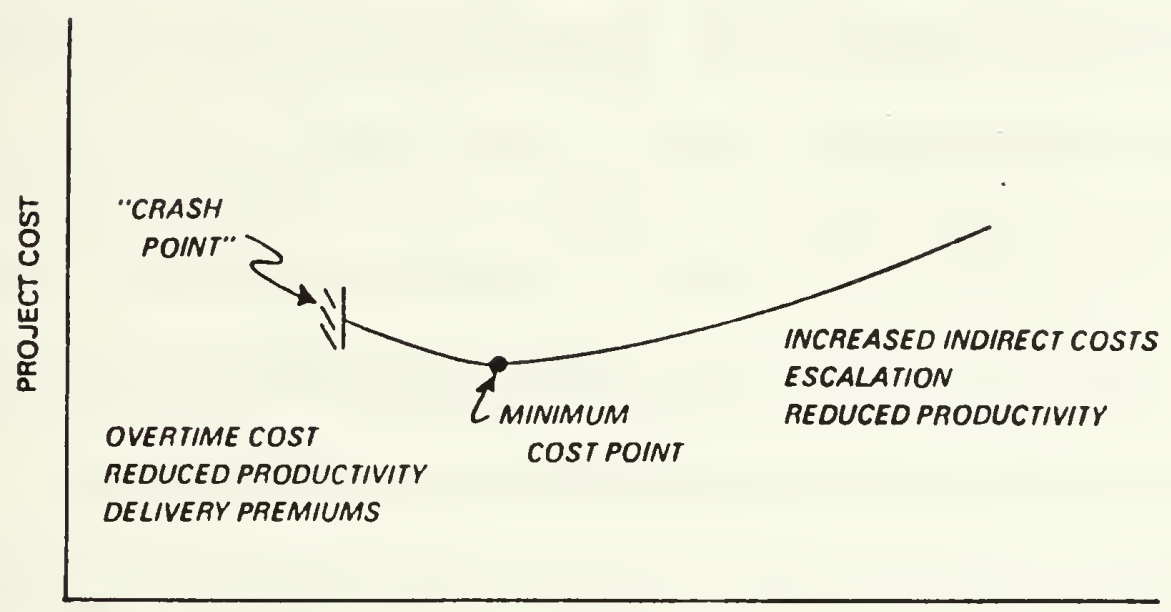

PROJECT DURATION (TIME)

Reproduced from "Managing the Engineering and Construction of Small Projects" by Richard E. Westney. 



\section{CHAPTER TWO \\ FACTORS WHICH AFFECT DURATION}

\subsection{Introduction}

Successful completion of a contract is not something that can happen automatically. Planning for it is essential. The contract is considered the means by which an owner communicates his desires to the contractor.

Each party has agreed upon rights and responsibilities. This portion of the report will examine those factors which influence the duration of the contract. Factors can be divided into two groups, those which lengthen the contract (nearly all of the factors) and those which shorten the duration (very few). Some of the key factors affecting duration are:

project size (small, medium, large, super, and mega), type of construction, type of project, type of contract used, type of materials used, local conditions, 

administrative conditions of the contract, project delivery method, and other factors.

Each of these factors has the tendency to increase the length of the contract depending on their interactions. As will be discussed in the following paragraphs each factor can have a differing level of effect on the duration. While no quantitative analysis can be presented here, it is sufficient to note that each of these factors will be present in all contracts. The owner is therefore encumbered to analyze his situation for their effects.

\subsection{Size of the Project}

It is no surprise that a larger facility can and often does take longer to complete than a smaller one. For the purposes of this report project size has been grouped into five areas, small, medium, large, super, and mega. This is based purely on dollar cost, which unfortunately can be very misleading. Richard Westney describes in his book "Managing the 

Engineering and Construction of Small Projects" defines a small project as determined by the environment in which the project takes place. He state that a small project can range from $\$ 5000$ to 50 million dollars. That is quite a range to consider small. However, typically public agencies often have slightly more complex and sofisticated rules for contracts depending on the anticipated contract dollar volume. Therefore, applying that logic, projects can be grouped by size into five categories:

small, up to $\$ 500,000$ and/or lasting 6 months to 9 months, medium, from $\$ 500,000$ to 2 million and/or lasting up to 18 months large, from 2 million up to 100 million and/or lasting over 18 months, super, over 100 million and/or lasting over 2 years, and mega, considered as a series of large or super sized projects, and/or lasting over 5 years.

While dollar volume is misleading in determining the size of the project, it can serve to illustrate the idea that a larger dollar volume 

contract will often take longer. However, one has to consider the economy of scales of large projects which are not complicated in terms of the work required. These projects could be completed more quickly than other less costly but more complicated in terms of materials, equipment, or processes used to produce the facility. Clearly, the point is that a larger dollar cost will serve only as a guide to roughly defining the contract duration.

\subsection{Iype of Project}

This factor is divided up into four areas; residential, building construction, industrial, and engineering. ${ }^{2}$ Clough provides definitions for each of these segments of the construction industry. They are:

residential, represented by projects such as single and multiple family homes; condominiums; multiunit town houses; low rise, garden-type apartments; and high rise apartments, 

building construction, including projects such as:

institutional; educational; commercial; social; religious;

governmental; and recreational,

industrial, projects such as manufacturing plants, chemical

complexes, large production facilities, and

engineering, projects generally designed by engineers such as

power plants, dams, interstate highways, bridges, sewage

treatment plants, irrigation and flood control projects, and

other public oriented works. ${ }^{3}$

\subsubsection{Residential}

The type of project will say a lot about the type of owner. Generally residential construction in the United States is done by private builder-vendors who resell the homes to individual buyers. However, federal agencies such as HEW and DOD do contract for housing for their constituents. State universities would also fit into this category for the 

purposes of constructing dormitories. However they would not be considered typical of the residential housing market. The point about residential construction is that it would generally fall into the small project category and typically be done by a private concern. Residential construction has been reported by Clough to account for 30 to 35 percent of the annual construction industry volume. ${ }^{4}$ These projects tend to be labor intensive and their contract duration can be varied tremendously. An example of this wide variation is a house constructed in Gainesville, Florida in 1982 . This house was completed in 24 hours after the foundation and underground utilities were completed. Typically though, residential construction tends to be of short duration usually lasting only one to three months. Because of that, little contract planning is done on the part of the builder vendors. The contract duration for a private owner is generally determined by the architect or engineer, if there is one. As such most architects use their experience with similar sized projects as a guide to determining the contract duration. The same can be said for most developers. 5 



\subsubsection{Building construction}

This category of project accounts for 35 to 40 percent of the annual total new construction. ${ }^{6}$ Design is predominately performed by architects with engineering design services included as necessary. ${ }^{7}$ This is the largest portion of the industry. These projects can be any dollar volume. Building construction is generally dominated by projects that are medium to large in size with very few (small and mega sized projects) at either end of the scale. The World Trade Center in New York would quickly come to mind for a super sized project. A mega project would be the construction of a new city such as those completed in Saudia Arabia during the 1970's. In any event, projects in this category need considerable planning in order to control their cost and duration.

\subsubsection{Industrial}

Clough considers this to be the smallest category of the construction industry, accounting for only 5 to 10 percent of the volume. He states that it is dominated by specialized firms who do both the design and field construction of these projects. These contracts are generally privately 

financed and owned. The contract duration is usually set in the proposal from the designer-builder. The techniques used by them will be discussed in Chapter four.

\subsubsection{Engineering Construction}

This category accounts for 20 to $25 \%$ of the construction volume annually. These are generally public financed and owned, either designed by the owner's staff or by architect-engineer firms under contract. In theses cases, the contract duration would be initially set by the designer. This topic will be explored more fully in Chapter Three. It is sufficient to say that engineering construction projects are generally large to super in dollar volume and can take over two years to complete. In these contracts accurate planning can be highly beneficial. However, the dollar benefit may be difficult to quantify especially for roads, airfields, and the like. Generally, the public agency responsible for the contract will assign a public benefit quantity per unit use (usually dollars per mile or some other appropriate usage). This allows a delay in completion to be quantified. However, as delays are excused, the contractor will be 

relieved of the financial burden, but the public cost remains. With this happening all the time on construction projects, timely completion and the adequacy to plan carefully for it are two compelling reasons for adequate and accurate contract durations.

\subsection{Iype of Construction}

This factor can be defined as describing the physical nature of the project to be built. This involves the terms new construction, renovation, horizontal, or vertical. New construction is the building of a facility on any site where there previously was no other facility. This will include demolition and removal of a previous facility if there is no plan to reuse any portion of that facility. Renovation on the other hand, is the reuse of previous facilities after modification, repair, or alteration. Horizontal construction is typically associated with the building of roads, highways, pipelines, and other such facilities that have their predominate dimension in the horizontal plane. Vertical construction encompasses buildings and other facilities where, generally, the construction is above ground. 



\subsubsection{New Construction}

New construction is the easiest and considered to be the "cleanliest" type of construction to perform. New construction is associated in the building of a facility on a site where there was no other facility or the previous one has been removed. New construction is considered "cleaner" because it generally is not necessary to match new materials with the existing. Likewise, incompatible materials and technology are often encountered in renovations. As compared to renovation, the actual construction can have fewer problems such as unforeseen conditions in existing structures and materials, problems with code violations, safety, and differing quality of construction. Generally, all of the materials to be used in the construction are new. In determining the contract duration, the designer can use any of the techniques to be discussed in Chapter Three.

\subsubsection{Benovation}

Renovation is the remodeling, repair, or alteration of an existing facility for reuse. This type of construction can lead to numerous 

problems of unforeseen conditions and additional repairs. Renovation can be further complicated by the type of occupancy in the building.

Renovation of an abandoned facility can be performed faster than that of one occupied or partially occupied. This is based on the belief that interference from the occupants will reduce the productivity of the contractor either by limiting his operations to certain times of the day or by requiring additional work in the form of protective barriers against dust, noise, and debris. A contract to renovate portions of a hospital should be expected to take longer than the renovation of an abandoned warehouse. Aside from the different types of occupancy, the presence of other people in the facility will undoubtedly influence the duration. Size of the project will also influence the duration.

\subsubsection{Horizontal}

Another factor to consider is the predominate plane of the construction, either horizontal or vertical. Horizontal construction is often associated with roads, pipelines, highways, and others facilities that are primarily linear or flat in nature. These types of projects can be 

considered as a series of smaller projects joined together. This is based on the fact that each individual task is overlapped by the follow-on task, since it is impractical to perform each task separately. An example of this is the building of a sewer line. A normal construction sequence is to complete one section of the line. These steps would be repeated over and over in each section until the facility was completed. The steps involved in a sewer line are clearing, excavating, shoring, placing pipe, bedding pipe, unshoring, and backfilling. A scheduling technique that maximizes the overlap of each task, in order to minimize the duration, is known as "Line of Balance". 8 The importance of this is that it can provide the owner with a more realistic model of the minimum possible contract duration. As will be discussed in Chapter Four, this is seldom done by state DOTs.

\subsubsection{Vertical}

Vertical construction encompasses all other types of facilities that do not lie in one plane. Most facilities fall into this category. The duration for this type of project can be determined by any number of 

techniques. A discussion of the predominate methods, CPM, bar charts, and judgement will be presented in Chapter Three. It is necessary now to point out that vertical construction is different from horizontal in the way the problems are attacked. However, to determine the minimum time necessary to perform the work, a logical sequence of work must be established. This is also true in horizontal construction. However, it is more pronounced for vertical construction where the exact order of work can be varied.

\subsection{Iype of Material}

A fourth factor to consider in the contract duration is the type of materials used for the facility. Five major types of materials come to mind, wood, concrete, steel, masonry, and metal buildings systems. Of these, cast-in-place concrete is considered to take the longest construction time. This is due to the fact that forms must be manufactured and installed prior to placement of the concrete. Additionally, curing of the concrete and stripping of the forms has to take place prior to finally completing the facility. With careful design, and the 

proper sequencing of the construction, this delay can be minimized.

However, as compared to other types of materials, concrete takes the longest. Structural steel can be erected faster and has no curing or forms that are associated with reinforced concrete. However, fabrication of the steel does take time. Again, a knowledgeable designer can minimize this time by selecting those members that are known to be readily available.

Wood construction is considered labor intensive. Due to the limited structural capability of wood as compared to steel or concrete, it is generally used in smaller projects, often residential construction. Again, consideration in the design can eliminate delay for unusual sized members not readily available. Masonry is also considered to be labor intensive. In larger facilities, masonry is used only as a veneer over the structural skeleton. In this fashion, it becomes only a cladding to be compared to other claddings such as metal siding or precast concrete panels.

Metal buildings systems are another choice. They offer fast erection and in recent times, a wide variety of styles and sizes. Metal buildings systems are generally associated with commercial and utility buildings, 

and are limited in height. Although some manufacturers have metal buildings designed to a height of five stories, most manufacturers feel they can not profitably compete with hot rolled structural steel shapes over this height. However, the Metal Buildings Manufacturers Association (MBMA) reported that in 1986 metal buildings accounted for $47.8 \%$ of the low rise non-residential construction market. Additionally, MBMA stated that " $A$ building systems project generally can be completed in one third less time than other types of construction. ${ }^{9} 9$ The importance of this is that construction time can be reduced over other types of materials. Additionally, since metal buildings are factory based, the average cost per hour was $\$ 9.01$ for the metal builders as compared to $\$ 13.03$ for the structural steel fabricators. Therefore, time and money can be saved if this material is selected by the designer. However, caution must be exercised if the full advantage of this system is to be realized. The designer must select from the available buildings otherwise the fabrication time could negate any possible gain over the other types of materials. Thus, careful planning from the designer and contractor is necessary to maximize the advantages. 

The point of this discussion is to illustrate that owners can have a huge influence over the contract duration and ultimately their wait for the facility. How or why they chose a certain material will represent the value they place on duration in the procurement process.

\subsection{Iype of Contract}

The fifth factor to be considered in this chapter is the type of contract. While the vast majority of construction contracts are of the fixed price variety, the owner should be aware of the effects the contract type can have on delivery. The types of contracts under consideration are fixed price, both lump sum and unit price, cost reimbursable with fixed fee, cost reimbursable with percent fee, phased construction, and convertible contracts.

Each contract has advantages and disadvantages in fulfilling the owner's goals of quality, price, and timeliness. First, each type of 

contract should be described in general terms then considered in relationship with each other for effects on contract duration. Figure $2^{10}$ is an illustration of the relative effectiveness of each type of contract in achieving the owner's goals. Figures $3^{11}$ and $4^{12}$ are included to summarize this discussion. 



\section{Figure 2}

\section{Relative Effectiveness in Achieving Owner's Goals}

Type of Contract

Firm Fixed Price

FFP, w Completion bonus

FFP, w/target estimate

FFP w/escalation

Cost Plus Percentage of Cost

Cost Plus Fixed Fee

Cost Plus incentive Fee

Cost Plus Award Fee

Time and Materials

Labor/Equipment hour
Low Cost $40 \%$
High Quality $20 \%$

\section{Speed of Work Average Score $40 \%$}

$\begin{array}{llll}\text { A } & \text { F } & \text { F } & \text { C } \\ \text { A } & \text { F } & \text { F+ } & \text { C } \\ \text { B+ } & \text { F } & \text { B } & \text { B } \\ \text { B } & \text { F } & \text { F } & \text { C } \\ \text { F } & \text { A } & \text { B } & \text { C } \\ \text { F+ } & \text { B } & \text { B } & \text { C } \\ \text { C }_{+} & \text {C } & \text { B } & \text { C+ } \\ \text { C+ } & \text { B } & \text { B+ } & \text { B } \\ \text { F+ } & \text { B } & \text { A } & \text { C } \\ \text { F+ } & \text { B } & \text { A } & \text { C }\end{array}$

C
C

$$
\text { C }
$$

C

$+$

B

C

C

Legend

$$
\begin{aligned}
& A=\text { Highest Effectiveness } \\
& B=\text { Average to Good Effectiveness } \\
& C=\text { Poor to Average Effectiveness } \\
& F=\text { Deleterious Ineffective }
\end{aligned}
$$

Reproduced from "Contractual Relationships in Construction" by

Stephen E. Smith, Woodrow W. Wilson, William C. Burns, and Robert A.

Rubin, Journal of the Construction Division. Proceedings of the American Society of Civil Engineers, December 1975, p 911. 



\section{Figure 3}

\section{Summary of Contract Types}

\begin{tabular}{|c|c|c|c|c|}
\hline Attribute & Highly Competitive & $\begin{array}{l}\text { Reimbusable } \\
\text { Competitive }\end{array}$ & $\begin{array}{c}\text { Reimbusable } \\
\text { W/Fixed Fee } \\
\text { Competitive }\end{array}$ & $\begin{array}{l}\text { Unit Price } \\
\text { Competitive }\end{array}$ \\
\hline $\begin{array}{l}\text { Contracting Time } \\
\text { Required }\end{array}$ & Long & Short & Short & Medium \\
\hline $\begin{array}{l}\text { Scope of Work } \\
\text { Definition }\end{array}$ & $\begin{array}{l}\text { Detailed Definition; } \\
\text { Fixed Scope }\end{array}$ & $\begin{array}{l}\text { General Definition; } \\
\text { Variable Scope }\end{array}$ & $\begin{array}{l}\text { General Definition; } \\
\text { Variable Scope }\end{array}$ & $\begin{array}{c}\text { Semi-Detailed Definition } \\
\text { Variable Scope }\end{array}$ \\
\hline $\begin{array}{l}\text { Client Risk of Cost } \\
\text { Overruns }\end{array}$ & Lower & Higher & Moderate & Moderate \\
\hline Potential for Claims & High & Low & Low & Moderate \\
\hline $\begin{array}{l}\text { Market Conditions } \\
\text { Required }\end{array}$ & Competitive & None & None & $\begin{array}{l}\text { Moderately } \\
\text { Competitive }\end{array}$ \\
\hline Negotiation Effort & High & Low & Moderate & Moderate \\
\hline $\begin{array}{l}\text { Control and } \\
\text { Administrative Effort }\end{array}$ & Low & High & Moderately High & Moderate \\
\hline
\end{tabular}

Reproduced from "Managing the Engineering and Construction of Small

Projects" by Richard E. Westney 



\section{Figure 4}

\section{Project Duration Vs. Contract Time}

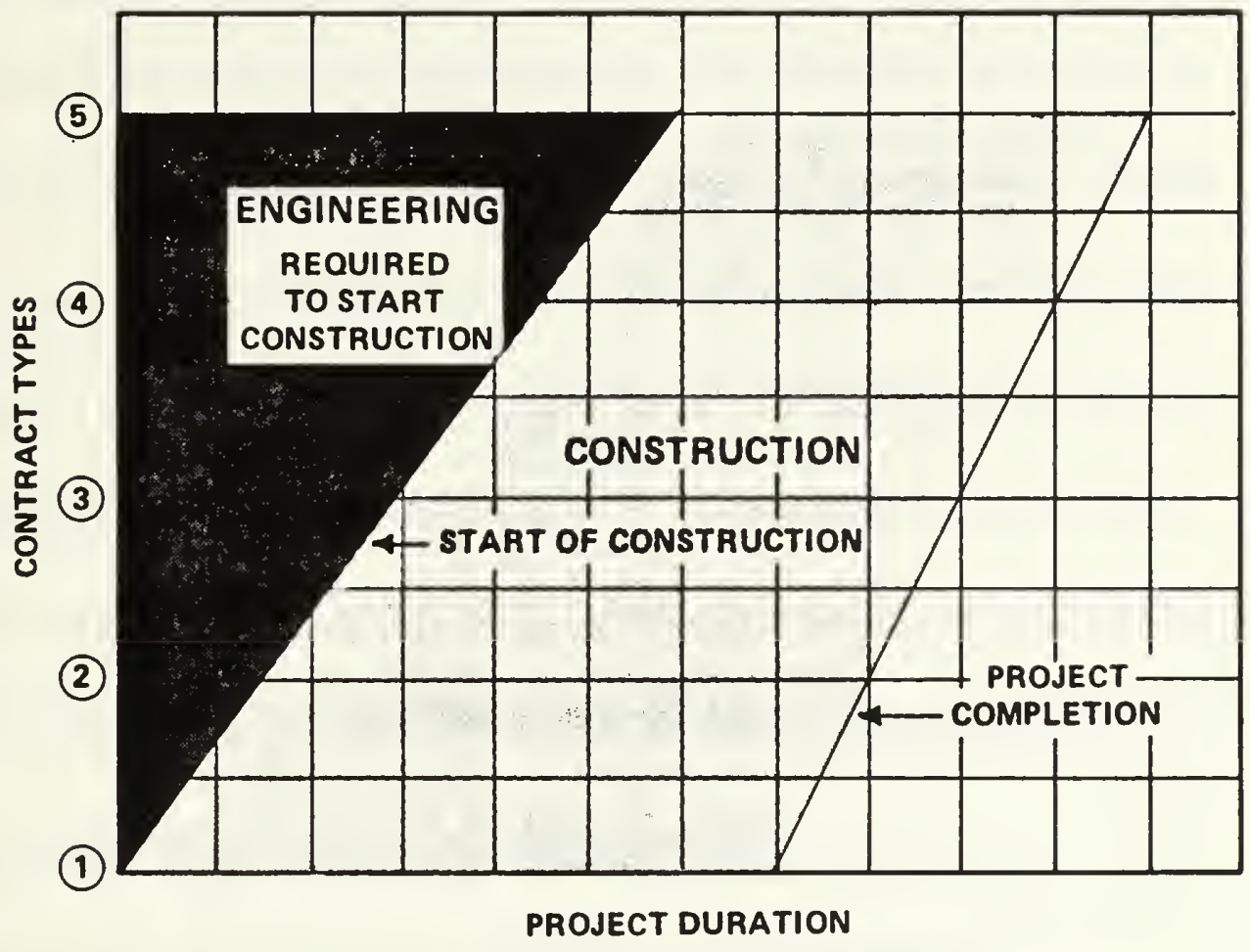

1 COST REIMBURSABLE W / \% FEE

2 COST REIMBURSABLE W / FIXED FEE

3 TARGET PRICE

4 GUARANTEED MAXIMUM PRICE

5 LUMP SUM FIXED PRICE

Reproduced from "Contractual Arrangements Report A-7", A Construction Industry Cost Effectiveness Project Report, by the Business Roundtable. 



\subsubsection{Lump Sum}

This is the most prevalent type of contract used in construction. This contract is basically an agreement that details the work to be done in a stated period of time. The owner is required to give a full and complete description of the work to be accomplished. The attraction for owners is that the total construction costs are known prior to construction. Public agencies routinely competitively bid this type of contract. Another major advantage is that it is an excellent incentive for the contractor to control costs and thereby enhance productivity. ${ }^{13}$ The owner however must accept the responsibility of providing significant amounts of information to the contractor. Among this information is a detailed scope of the project (detailed plans showing quantities and locations of work), a schedule for completion (the duration stated in the agreement), the desired quality of construction (the specifications), and the adequacy of the site conditions. ${ }^{14}$ Some limitations must be recognized in this contract, namely the duration from project identification to occupancy, and the need to accurately and completely define the project at the time of bidding. For these and many other reasons, the lump sum contract is generally used in residential and building construction. 15 



\subsubsection{Unit Price}

This type of contract is based on the estimated quantity of certain, well defined items of work and costs per unit amount. A disadvantage is that the owner will not know the exact cost of construction until project completion. In keeping with this liability, the industry utilizes this contract on such repetitive work items as roads, highways, pile driving, and other horizontal type projects. Public owners use this type of contract extensively. In order to budget accurately for the costs, they utilize historical data and the estimated quantities in determining their cost estimate. For duration, production rates are utilized as a convenient tool.

\subsubsection{Cost Reimbursable}

This type is utilized when the owner perceives that a fixed price contract is inappropriate or undesirable. Generally, the owner and contractor negotiate a scope contract because the exact nature and quantity of the work may not be fully defined. Plans and specifications are usually not completed by the time the negotiations are completed. 

Again, the exact cost of the construction is not known until the project is completed. With this arrangement, the contractor can receive his fee based on one of two methods, fixed fee or percentage of costs.

The fixed-fee-cost-plus contract is established where the nature of the contract can be fairly well defined, and a reasonably good estimate of the cost can be computed. The fee to the contractor is a negotiated amount that is based on the complexity of the work, size of the project, estimated time of construction (estimated contract duration), hazards involved, location, equipment and manpower considerations. Since the fee to the contractor does not change, this provides motivation to him to prosecute the work as diligently as possible. This is based on the belief that the contractor has allowed for his overhead in the fee to run the full term of the contract. If he completes early then less overhead is expended on the contract and that increases his profit. The expediting by the contractor will deliver the facility to the owner earlier. 

The other type of fee arrangement is the percentage of costs fee. The percentage is determined by either a fixed amount or a sliding scale arrangement. The contract is advantageous for poorly defined scope contracts where time is not available for advanced preparation of bidding documents. Wars and other periods of extreme emergency are examples of use of this contract. Initial clean up operations from natural disasters have been contracted for with this type of contract. Clough gives other examples such as remodeling or expansion of facilities where services must be maintained as uses for the cost-plus-percent-of-costs contract. The major disadvantage is that there is little incentive to control costs on the part of the contractor. The owner must include provisions for this with the inclusion of an "upset price". ${ }^{16}$ An upset price is a maximum amount agreed upon by the owner and the contractor which when reached, will require the contractor to pay any additional costs to complete the contract. However, where the owner needs to start construction in the minimum amount of time, this contract can be utilized effectively. 



\subsubsection{The Convertible Contract}

This is a hybrid of a cost reimbursable contract and a fixed price.

Usually the contract starts out as a cost reimbursable (when engineering and project scope are poorly defined) and then converts to a fixed price when the engineering is complete or accurate enough to determine a fixed price. The owner and contractor can share equally in the risks associated in the specifications and other uncertainties. A draw back with this is that the fixed price portion of the contract becomes a negotiated agreement and is not subject to any competition as in the pure fixed price contract. ${ }^{17}$ However, this type of contract could easily be utilized on phasing of construction where the engineering time runs concurrently with construction time.

Figure 4 (page 29) illustrates the discussion regarding contract type.

The owner can make a knowledgeable decision in order to reduce contract duration. He must effectively judge the relative importance of all the factors in achieving his goals. 



\subsection{Lecal Conditions}

Along with the other factors mentioned earlier, the owner has some choice over the effects of local conditions. This factor is meant to consider the size, location and accessibility of the site, climate conditions, and administrative restrictions of zoning or environmental requirements. While the owner can have some control over the selection of site, such other factors as weather, zoning, and any other restrictions he may only be able to influence slightly. Weather can only be influenced by picking the time of year to start construction. The influence of these factors can not accurately be predicted prior to start of the contract. Unfortunately, not every environmental requirement may be known prior to construction. This can lead to a longer wait for the facility than planned.

\subsection{Administrative Requirements}

This discussion of factors, so far, has been centered on portions which affect the actual work. Administrative requirements are those items included in the contract which facilitate the owner's ability to administer the contract successfully. Many of the requirements are the 

result of court decisions against both owners and contractors which have cost them considerable time and money. Some of the present requirements are:

submittals of proposed materials, engineering drawings, plans of erection, and equipment for approval, demolition plans, safety plans, quality management plans (if required), certificates of insurance, performance and payment bonds, administrative requirements set by the owner, security requirements such as citizenship and loyalty of workers, scheduling and planning requirements in the contract, and owner/user operational requirements.

The contract specifications will define each of these requirements for the contractor and owner to fulfill. There is however a tendency by 

both owners and contractors to ignore the time required to properly prepare these items for submission and review. Careful planning and execution is required of each party in order to complete these items. However, little thought is given to including a period of time in the contract for these items to be performed. Often, public agencies will be anxious for the contractor to begin work as soon as possible after award of the contract. This is often driven by a desire to show the user that work is beginning on the promised facility. However, there may be other requirements in the contract that prohibit the contractor from starting as soon as possible because of security requirements, needs to relocate the present occupant of the facility (especially true if the project is a renovation), and approval for insurance, bonds, demolition plans, and other administrative requirements. It is not uncommon for these items to take over 30 days to complete. Therefore, it is easy to use the first month of the contract in completing the initial administrative requirements. The point of this discussion is that adequate time for preparation and review by the contract administrator should be included in the contract. It is unrealistic to expect submission of all these items within 10 to 15 days 

after contract award. Careful thought is required by owners to include time for these items in the basic contract. The benefits will be well worth the wait if a lawsuit can be avoided.

\subsection{Other Factors}

While the previous factors all have the premise that the owner has some influence over them, there are numerous factors which the owner can only hope to influence. Chief among these are the contractor related factors. This includes the size of the work crew, equipment, and construction methodology. Most public owners stay away from dictating the construction methodology to the contractor, preferring to have them manage their own assets. Most owners are aware that advancing technology can shorten the time to perform construction, but unless they specify the new technology or it is seen as cost effective to the contractor, the owner will only get the "accepted" technology from the contractor. Therefore, this report will only mention in passing these potential factors of decreasing duration. It is sufficient to say that the astute owner can influence the effect of these factors by knowing and 

adequately planning for them. By adequately planning, it is meant to account for them in the budget for time and money.

\subsection{Delivery Systems}

So far the discussion has revolved around the traditional delivery method of an architect/engineer designing the proposed project and the owner bidding and awarding the contract to the lowest responsible, responsive bidder. This is considered to be the simplest method. It has however, two serious drawbacks. It is the slowest and it costs the most. 18 To overcome these drawbacks, owners have sought to shorten their wait by utilizing other delivery systems. These include construction management, design-build, and combinations of all three.

\subsubsection{Construction Management}

Construction Management (CM) uses the construction experience of the contractor in the early design phase to suggest changes and to help organize the project to reduce the cost and time. $\mathrm{CM}$ is based on the the idea that as design decisions are made, the construction process can begin. 

By overlapping, the time of delivery can be greatly shortened. ${ }^{19}$

Construction managers will perform estimating at each phase. By doing so, they can often offer a guaranteed maximum price at about the 60 percent design stage. Many owners feel this is preferable to the traditional delivery system.

Construction management (CM) has evolved into a significant part of the industry so that during the 1970's the General Services Administration (GSA) relied on it heavily to deliver their need for office spaces. GSA required the $\mathrm{CM}$ to perform the following:

prepare cost estimates of system contract drawings, prepares system price limit and bid equalization factors, and prepare pre-bid schedule of design and construction for inclusion in the Invitation for Bids. ${ }^{20}$

This system was abandoned during the early 1980's in favor of a traditional delivery system. However, CM has continued to grow significantly. For some owners, this delivery method is highly preferable for the savings in time and money. 



\subsubsection{Design-Construct}

Design-construct or design-build is the name given to the integration of the design and construction phases into one single contract between the owner and the contractor. This system came from the large construction companies hiring full time in house consultants to offer the owner a complete package of design and construction for a single price.

Owners are attracted to this system because it offers economy of time and cost by melding the functions together. ${ }^{21}$ This type of contracting is used extensively for industrial construction. Owners like the advantage of having one single entity responsible for their entire project.

As a delivery system, design-construct will shorten the time for delivery in much the same way as construction management. The construction firm familiar with the type of project will utilize a design team either in house or by contract to perform the design. There is close coordination between the designers and constructors to reduce the duration of the procurement. Additionally, the design-construct firm works closely with the owner in all aspects of the project, planning, 

design, cost control, scheduling, site selection, financing, etc. This gives the owner the expertise of two closely related fields of design and construction.

\subsection{Conclusions}

All factors discussed have varying effects on the contract duration. Their impact is difficult to measure. However, the owner must understand the role each has in determining duration. Figure 4 (page 29) illustrates the effect contract type has on project duration. This figure shows that engineering time is linearly related to contract type and project duration. This may not be true. However, the point where construction can commence has a direct (though not necessarily linear) relationship with project completion. The other factors such as material choice, type of construction, type of facility, etc all affect the duration. A consequence of these factors is that the owner must chose among conflicting goals when selecting his facility. The next step is to consider some of the available methods for determining contract duration. 



\section{CHAPTER THREE \\ DISCUSSION OF METHODS FOR DETERMINING CONTRACT DURATION}

\subsection{Introduction}

This report will consider four methods of determining contract duration in the detailed discussion. In reality, the methods available are as different as the owner's differing goals. However, there are four which cover the most widely accepted and practiced methods. These are:

CPM, production rates, parameters, engineering judgement and experience.

CPM is the abbreviation for critical path method. This involves the logical connection of activities into a network to show their construction sequencing and dependencies. Many names have been associated with 

critical path networks such as arrow diagrams, precedence diagrams and advanced precedence diagrams. All of these techniques mentioned are derived from the same desire to logically illustrate the conduct of the construction work and to determine the minimum or optimum amount of time necessary to perform all of the work required. CPM and the other similar networking techniques have the flexibility to solve many other scheduling problems. However this discussion will be limited to construction problems. Originally, networking such as CPM came about as a desire to solve scheduling problems.

\subsection{CPM to Determine Duration}

Since CPM was invented to solve the scheduling problems that arose after award or start of construction, the next logical thing was to predict the duration of a project prior to awarding the contract. In order to use a CPM technique, either arrow, precedence, or advanced precedence, the "planner" (either the owner or the owner's agent, i.e. designer or engineer) must break the project down into smaller activities. Some planners call these "master activities" or major tasks. Generally, they are large sections 

of the work such as masonry, concrete, electrical, sitework, etc. The size of the project and the planner's desire for detail will determine the number of master activities. Harris gives a detailed method for constructing both an arrow diagram and precedence diagrams. Once the number of master activities and their logical arrangement is determined, the question of how to determine each activities' individual duration must be addressed. This is the basic problem with CPM. While it allows the planner great flexibility in executing the logic of the construction, the duration of each individual activity is still unknown. This technique is only as good as the input data. This is why it is only a scheduling technique and not necessarily accurate as a method of determining duration. Many planners combine CPM with some other technique such as production rates or engineering judgement and experience to determine the activity duration. Once each activity duration is known, the overall critical path can be determined by either manually performing a forward and backwara pass through the network, or utilizing a computer to perform those calculations. This involves the summing of the earliest start and finish times for each activity according to the 

predetermined dependency logic. The critical path then is the chain of activities with the shortest total time to complete the project.

Some problems exist with this technique. First, it is only a partial solution to the dilemma. That is, it shows the duration only after the individual activities' duration are known. It does nothing to help determine their duration. Secondly, the logic used by the planner may not be the logic the successful contractor will use. Most owners leave the actual planning and scheduling of the work to the contractor in order to utilize his expertise with men and equipment. Thirdly, the CPM diagram will only give the planner the number of work days required to complete the work as planned. This number may not be (and often is not) the actual contract duration. Some method is required to convert workdays into calendar days in order to determine the contract duration. Additionally, unless an activity is included to represent the administrative requirements of the contract, no time will be accounted for in the duration. 

As can be seen from those shortcomings, CPM techniques do not necessarily make it easy. However, they do perform a vital task of forcing the planner to consider the elements of work in the contract. Given that framework, CPM goes a long way in deriving a "reasonable" duration.

\subsection{Production Rates}

A method common to repetitive type work involves the use of production rates. This method utilizes known work productivity rates and known quantities of work effort required to determine durations. The productivity rate is defined as the quantity of work performed for a unit of time. In order to find a duration, the total work quantity is divided by the productivity rate for that type of work. An example of this is to find the duration of earth work required to move 10,000 cubic yards of fill a certain distance. A planner would determine the production rate, say 100 cubic yards per hour. Then the duration of the activity is $10,000 \mathrm{cy} / 100 \mathrm{cy} / \mathrm{hr}=$ 100 hours. 

Two immediate problems arise from this method. First, the productivity rate is difficult to measure or determine. It is the key to the problem, yet very little data has been collected on it. As can quickly be seen, productivity rates will vary depending on many reasons such as type of work, size of crew, weather, location, time of day, skill of the crew, etc.

In order to solve this problem, the planner has several choices. He can observe a similar operation to measure its productivity, he can assume a "reasonable" productivity based on his experience, or he can utilize any number of planning and estimating books such as Means Construction Cost Data or Richardson's Rapid Estimating System. These books are only averages of reported productivity and can be erroneous if the situations that they apply to are not the same as those in the activity. However, they can provide an average productivity rate that should only be used as a guide.

Secondly, productivity rates do not take into account the concurrency of many construction activities. The calculations provide the raw data for durations but they do not show sequencing dependencies, and overlapping of 

activities. Thus, production rates are only part of the solution to durations. As was discussed in section 3.2, productivity rates can be combined with a networking technique to establish a duration for the project. Again, this is not a contract duration since other elements such as any administrative requirements that are included in the contract must be accounted for in the duration stated in a contract.

\subsection{Parameters}

The name given this method is actually a series of methods that have been grouped together. A parameter is a constant value applied to some aspect of the project to produce a quantity of the duration. This multiplier can be related to the physical aspects or the dollar value of the project. An example of a physical parameter would be the building type, construction materials used, square footage, or volume enclosed. Logically, one would expect a hospital to take longer to build than an office or warehouse. Thus, for the given size (square foot, or volume of air space enclosed), the factor would determine duration of construction. 
Another, yet related, approach to this method is to determine (estimate) duration based on a cost factor. This method assumes that for a given type of project, the contractor can complete a certain number of dollars worth of work per unit of time. The most common unit of time is the day. Similar to a productivity rate, the cost parameter would take the estimated cost of the project times the cost factor per day to yield duration. By careful estimation, the cost factor must roughly account for many variables such as building type, weather, construction materials, location, and the other factors which affect duration. Thus, this method will only yield a rough estimate for the project duration. When combined with a CPM or another form of analysis, it could produce a duration closer to the optimum available for the project.

There is one significant problem with a cost parameter to determine duration. It is inflation dependent. The planner who uses this method must keep the data current with the industry in order to make the calculations meaningful. Unless the parameters are updated regularly, they become 

inaccurate. Thus, the planner must update the information he uses in order to accurately solve the duration problem.

\subsection{Engineering Judgement}

Many of the difficulties with the previous methods can be roughly quantified in an approach involving the designer's judgement. This method involves the use of the "expertise" of those familiar with the project.

Design engineers and architects who have created the design for the project are expected to use their judgement and experience to determine the contract duration. Logically it makes sense that those most familiar with the project should specify the contract duration. This assumption is based on the belief that most designers are knowledgeable about construction and the methods currently being used in the industry. That is, however, untrue.

Most designers are unaware of how the construction would be accomplished and are unable to adequately plan for it. The danger of this method is that it relies on the experience of some one unfamiliar with the construction procedures that will be used to produce the facility. This can be overcome by using construction management or design-build as discussed in sections 

2.10.1 and 2.10.2. However, a designer will often utilize the duration of a similar project as a guide. The duration is then determined based on how the designer sees the project proceeding. This has some major problems.

First, if the building is "one of a kind" or the the first ever built, then perhaps the engineer has no experience to draw upon. Secondly, just because he has numerous years of "experience" does not mean that it is correct or is even applicable to the project he is considering. However, many owners believe that they must rely on the experience of designers. Designers also believe in their experience with similar projects. Unfortunately, this reasoning entirely misses the point about determining contract durations. Experience only provides information about what has worked in the past. It does not tell the owner what is the optimum duration for his project or analyze the project for those items which could be changed to reduce the duration. 



\section{CHAPTER FOUR \\ CURRENT METHODS USED BY PUBLIC OWNERS}

\subsection{Introduction}

Chapter Three was an overview of the methods that could be employed to evaluate a contract for a proposed duration. This chapter will focus on the methods currently being used by governmental agencies. Those considered were the U. S. Naval Facilities Engineering Command (NAVFAC), the U.S. Army Corps of Engineers, state departments of transportation (DOT), and the city of Gainesville, Florida, Public Works Department. The first two are governed by one set of regulations which will be reviewed for its emphasis placed on contract durations. Since each state has a separate DOT, only an overview of the methods utilized was done. A summary of the findings is included in figure 5 (pages 67 to 69). For diversity, the city of Gainesville Public Works Department was interviewed as to their methods. Each of these agencies has several goals in common. However, their methods are very diverse. The emphasis was 

to interview agencies which represent each of the three layers of our governmental system, federal, state, and local. The federal level will be considered first.

\subsection{Federal Acquisition Regulations}

All federal agencies which contract for goods and services are subject to the United States Code of Federal Regulations, Title 48. Known as the Federal Acquisition Regulations System (FAR), section 12.102(b) provides general guidance concerning contract durations. The FAR lists six factors to be considered in the determination of the contract duration.

The FAR recommends that the contracting officer consider:

(1) Nature and complexity of the project,

(2) Construction seasons involved,

(3) Required completion date,

(4) Availability of materials and equipment,

(5) Capacity of the contractor to perform, and

(6) Use of multiple construction dates. 

While a myriad of potential parameters could be considered in determining contract durations, the six listed above appear to cover the most significant factors. In many ways, this list encompasses most of the factors considered in Chapter Two. Nature and complexity of the project is synonymous with the factors size and type of the project. The factor accounting for construction seasons is similar to those which account for the weather, listed under local conditions. Availability of materials and equipment can be considered a part of the discussion covering types of materials used. The capacity of the contractor to perform was discussed in section 2.9 under a discussion of the contractor's manpower, equipment, and methods. Thus, the FAR has listed 6 factors which in essence cover the majority of the factors which are considered to have the major impact on the contract duration. Now, it is important to consider how a specific agency would implement this guidance into action.

\subsection{U. S. Naval Facilities Engineering Command}

In amplification of the general guidance provided by the FAR, each federal agency has published their own separate guidance. The Naval 
Facilities Engineering Command, has published their policy and procedures for contracts in a publication known as "P-68 NAVFAC Contracting Manual".

Section 4-211 directs contracting officers to consider:

(1) complexity of the project,

(2) construction seasons,

(3) date work is required, and

(4) capacity of contractors to perform.

This is similar to the factors listed in the FAR, and those considered in this report. "Complexity of the project" is assumed to mean the type of project, either residential, building construction, industrial, or engineering. From this abbreviated list, emphasis has shifted to a user requirement date. This factor was not listed in the FAR. In continuing, the P-68 further directs contracting officers to extend contract time by 15 days to allow for the mailing of the required surety bonds. ${ }^{22}$ This extension is probably the result of decisions on contract disputes rendered by the Armed Services Board of Contract Appeals. This results in the contract time to be " $x$ " plus 15 days. For example, if a contract is 

advertised to be 180 days in length, the contractor will actually have 195 days from the date on a notice to proceed or award letter to begin and complete performance under the original contract. As can be seen, this discussion is only general in nature. No specific formula or work sheet is provided in the P-68. Therefore, the emphasis each factor is given relative to the others is up to the individual contracting officer.

Both the FAR and the P-68 section 2-211.3 recommend multiple completion dates as part of the general guidance for determining contract durations. There is a difference in that the FAR suggests this as a technique to determine the overall contract duration. The P-68 offers it as guidance on determining the contract duration and not as a factor. While the results may be the same, the intentions are clearly different. The FAR is more liberal by allowing contract durations to be determined by multiple completion dates. The P-68 doesn't state this to be a factor.

Multiple completion dates should be used when the contract has separable elements for which individual completion will have no bearing 
on the other elements in the contract. An example of this is a contract which covers several facilities which are not related in function and are often separated geographically. The P-68 recommends utilizing this technique of contracting when applicable. Projects which could utilize this technique must fall into a rather narrow band of qualification. Obviously, if the elements are unrelated, there are other regulations which probably prohibit or at least severely limit their grouping. Well defined scope statements often eliminate the use of this technique.

In addition, the P-68 in section 4-201 considers contract duration as part of "Division One of the Specifications". ${ }^{23}$ Division One is further defined as including the administrative terms of the contract, but not including the bidding information and contract general provisions or changes thereto. NAVFAC has tasked each Engineering Field Division (EFD) with the adequacy and accuracy of their contract durations. This is important since each EFD has given certain parts of its organization responsibility for different portions of the contract. Specifically, the Contracts division, Code $\mathrm{O} 2$, the Engineering and Design division, code $\mathrm{O} 4$, 
and the Construction division, code $\mathrm{O} 5$ share joint responsibility for contract durations. In reality, the EFD's are only able to limit their responsibility to the military construction program contracts and those special projects for which they oversee the design and award. There are local contracting officers at each major base which will oversee the design and construction of the smaller projects and be responsible for their contract durations. However, the EFD has been tasked with monitoring the contracting procedures of all the contracting officers within their geographical jurisdiction. Therefore, contract duration policy is set at the headquarters level and administered through out the world by the six EFDs.

In an interview with engineers at the Southern Division of the Naval Facilities Engineering Command located at Charleston, South Carolina, the following discussion resulted concerning their methods of determining contract durations. First, this EFD does not use any work sheet or empirical formula to determine contract duration. Since most of the projects are designed by contract, the architect/engineer firm "of record" 

is responsible for making the initial recommendation. The AVE is expected to consider:

\author{
submittal preparation, \\ long lead procurement of equipment, \\ size of the project, \\ complexity of the project, \\ user requirements, \\ construction practices, and \\ similar projects. 24
}

Upon receipt of the AVE's recommendation, and as part of the final design review prior to placing the contract out for bidding, the EFD utilizes a design team to examine the contract duration. This is done during a meeting with representatives from the user, the design manager, and the contract administrator to review the proposed duration. If there is disagreement, the members work out a compromise based on the urgency of need of the user. Thus, the EFD relies exclusively on the architect/engineer firm to make the initial recommendation. However, 
this does not occur in a vacuum. The AVE is usually very cognizant of the deadlines the EFD is working under to satisfy the user's requirements.

Since this is typical of each EFD's procedure to determine the contract duration, the question shifts to how the architect/engineer firm develops their recommendation. Section 4.8 will discuss how a design firm develops the initial recommendation for an owner.

\subsection{Corps of Engineers}

The U. S. Army Corps of Engineers is considered by many to be the largest construction organization in the world. Their organization is very similar to that of the U. S. Navy. There are however, distinct differences that make their organization worthy of note. Whereas the U.S. Navy has a codified set of instructions for contracting in the P-68, the Corps has no similar document. The Corps of Engineers is subject to the Federal Acquisition Regulations System and utilizes it as the basic guidance. They do however, modify the FAR through the issuance of supplemental instructions known as U.S. Army FARSUPPs. This is an army wide 
document that interprets specific sections of the FAR and tailors it to the Army's operation. Additionally, the Corps of Engineers issues supplements known as EFARS (Engineer FAR Supplements).

A third source of guidance for the Corps of Engineers is Engineer Regulation ER 1-1-11, "Network Analysis System". This regulation deals with the use of various network management methods known as critical path methods. The Corps of Engineers recognizes the importance of these tools to managing construction and has ordered all its field activities to utilize these systems in their contract administration. Paragraph six of the basic instruction delineates the use of the system and includes a discussion of contract time. The following is an excerpt from paragraph six.

"A comprehensive analysis of a major civil works project should include activities for preparation of design memos, and environmental impact statements, real estate planning and acquisition, preparation of plans and specifications, reservoir clearing, advertising and/or negotiation for construction, relocation and recreation contracts. Annual funding forecasts can be derived from early and late finish sorts of the analysis if costs have been assigned to each activity. Analysis can be used to set construction time prior to advertisement or select alternative contracting methods when user requirements preclude normal advertising." 25 

A review of current regulations held by the Jacksonville District of the Corps of Engineers indicates that no supplemental guidance has been issued concerning contract durations. Thus the six criteria established in the FAR is considered sufficient by the Corps of Engineers to establish contract durations.

In an interview with members of the staff at the Jacksonville District indicated that there are really only two criteria considered in determining contract durations. They are the user's needs and the estimator's experience with similar projects. ${ }^{26}$ This experience is based on three other criteria such as:

$$
\begin{aligned}
& \text { type of project, } \\
& \text { quantity of work, and } \\
& \text { average production rate. }
\end{aligned}
$$

Also mentioned by members of the Jacksonville District as considered in the contract duration was the user's requirements. The initial estimate is compared to the user's requirements and modified to fit the available time. ${ }^{27}$ Based on the criteria given, the main goal of the 

duration is to satisfy the user's requirements and appear reasonable. The differences are reflected in increased construction costs. The estimators indicated that in order to make the project fit the available time, they would estimate high to account for the premium of early delivery.

For complex jobs, the Corps of Engineers relies on civilian architectural and engineer firms to satisfy their design requirements. As is the case with the U.S. Navy, the Corps of Engineer lets the designers make the initial estimate of contract duration. This, again, comes back to the designer's experience with similar projects.

\subsection{State Department of Transportations}

In an effort to reach a large number of state agencies that contract on a regular basis for construction projects, the responses of a similar investigation by the Department of Civil Engineering at the University of Florida were reviewed. The responses were from a survey of state DOTs on how each determines contract duration. The responses included work sheets and booklets which detailed that state's method of determination. 

Figure 5 is a compilation of the responses and categorization of the methods with descriptions.

Since most of the work undertaken by DOTs is repetitive in nature, it is not surprising that a large number of the states utilize a production rate system. Twelve states failed to respond to the request for information. Of the remaining 38 responses, 12 were for production rates, 7 for historical experience or similar projects, 7 involved various factors including production rates, 6 utilized a network technique such as bar charts or CPM, 4 used a recommendation from a designer or review team, and the two remaining responses involved a graphing technique and a time and money bidding process. These two were the most unique and deserve a closer look. 



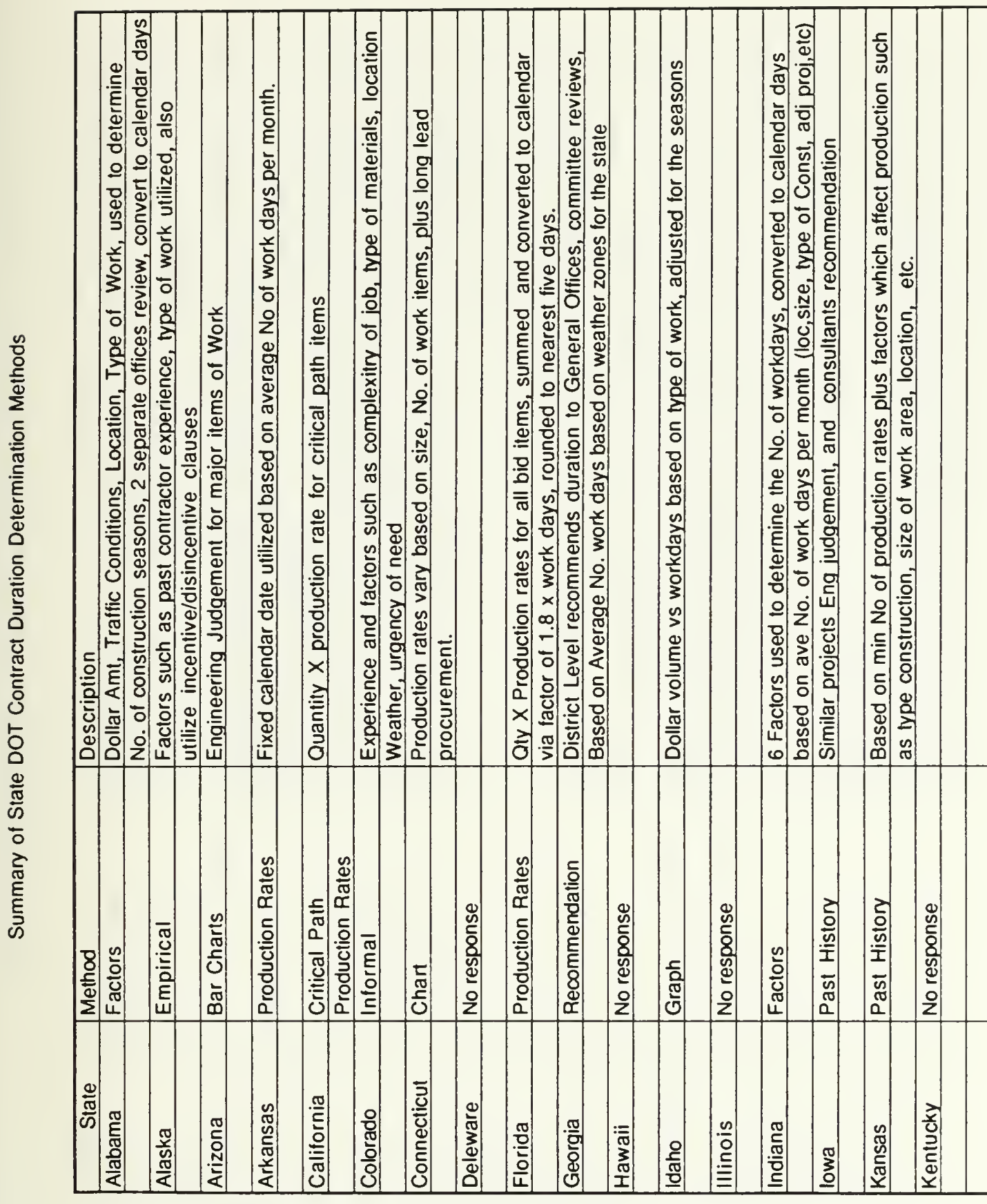





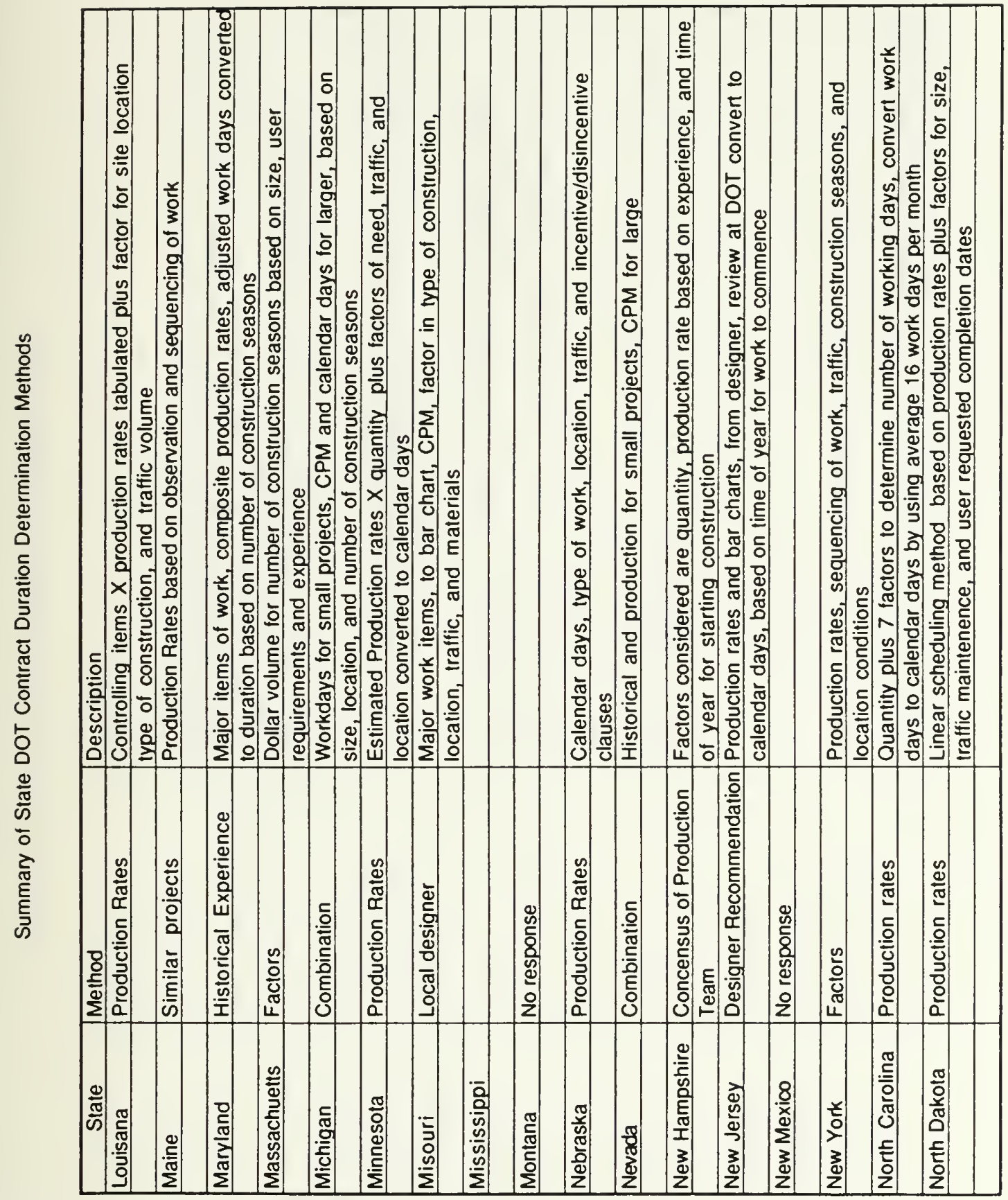











\subsubsection{Idaho Department of Transportation}

Idaho Department of Transportation determines their durations from an empirical graph that is based on dollar volume of the contract. This technique allows the owner to quantify his experience and production factors into the contract duration determination process. The graph also makes it relatively simple to calculate the duration without a lot of judgement from administrators on the effects of certain provisions in the contract. The graph is really a family of curves where each line represents a specific facility type such as bridges, buildings, and road work. The curves also separate out terrain which for roadwork can have a significant impact on production, and therefore duration.

To determine the duration, two factors are necessary, the estimated bid price and the facility type. The facility type is used to select the specific curve applicable. The estimated bid price can then be found on the horizontal axis. The contract duration is found on the vertical axis by finding the point where the estimated bid price intersects the appropriate graph of the type of project. Figure 6 is included to illustrate the following example. 

A building costing $\$ 500,000$ is to be built. The dollar amount is found on the horizontal axis. This line is traced vertically upward to where it intersects the curve representing buildings (top curve on the graph). The contract duration (in working days) is then read off the vertical axis as 175 days.

Figure 6 is actually a family of curves that reflect different production rates and other factors such as experience and construction seasons. The contract duration is read off the vertical axis where the dollar volume intersects the curve. In reality, this becomes a cost parameter method of determining contract duration. Since the graph is represented as working days, these will need to be converted to calendar days. One significant problem with this method is that it is sensitive to inflation and no apparent mechanism exists to correct for that. In order for the graph to continue to be accurate, some method of updating the information must be included. Idaho DOT has not included any information on this problem. 


\section{Figure 6}

\section{Idaho DOT Contract Duration Graph}

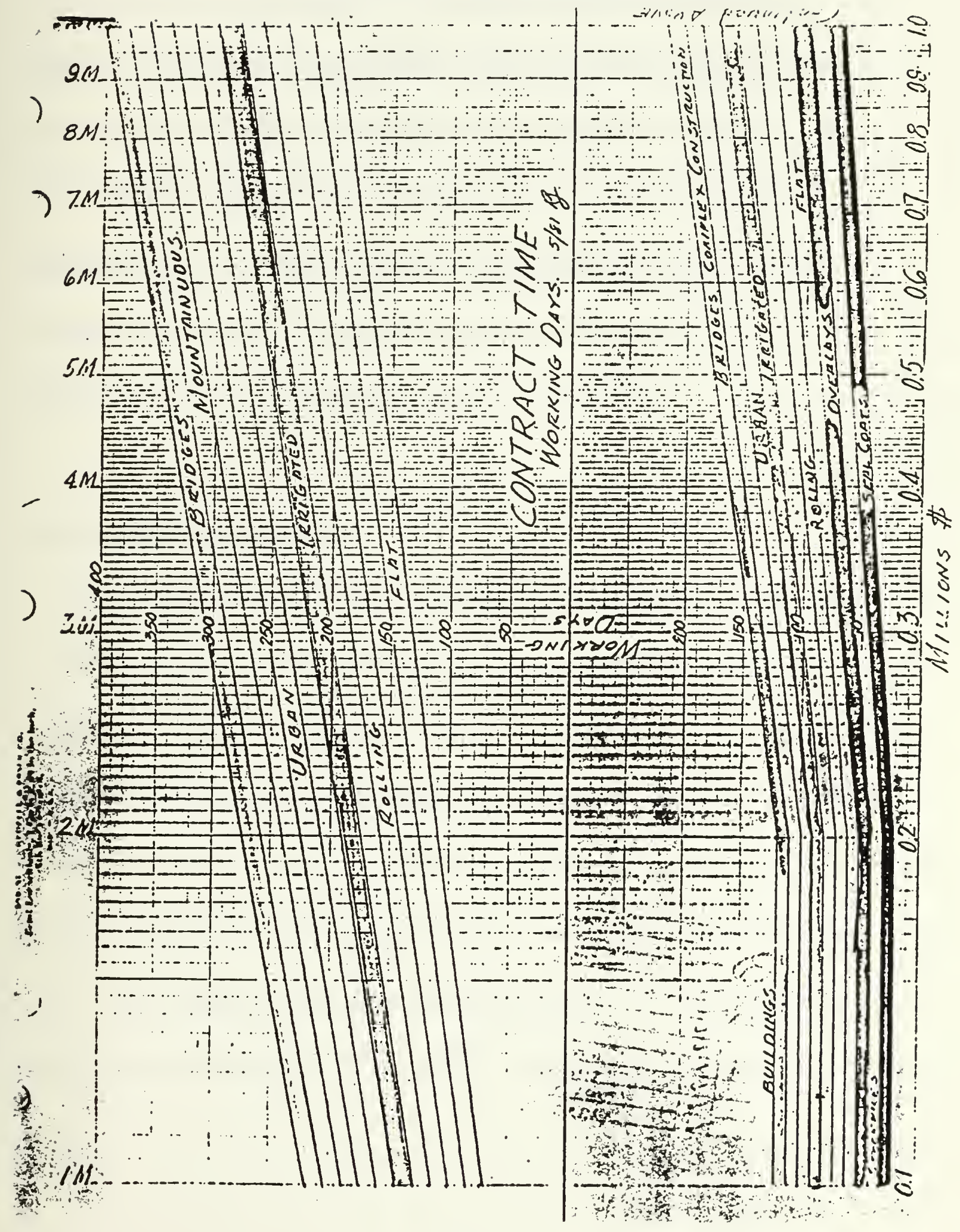





\subsubsection{Mississippi Department of Transportation}

Mississippi utilizes the most unique method of contract duration among all of the responses. Their method involves no set contract duration. The bidder provides both cost and duration for the job. This is based on the premise that all bids will be evaluated on two criteria. Each unit of time (day) is assigned an appropriate amount. Then bids are evaluated and the lowest total cost is awarded the contract. This is unique in two respects; it allows the contractors to set their own schedule, and it places a value on time in the contract.

\subsection{Competition for Delivery}

By contrast, P. D. V. Marsh points out that competition for delivery can bring on another set of difficulties. He states that delivery is interrelated to both the specifications and the price. Since changes in one affect the other, the owner must carefully balance these goals. A third leg to this is the question of quality. Westney illustrates the effects of increasing quality by showing a family of curves similar to figure 1 (page 10). When quality is increased, the optimum point for cost and duration moves up and to the right. Figure $7^{28}$ is included to illustrate this point. 

The effects that the owner feels are both increasing cost and duration of the contract. By including duration as a bid item, Marsh believes that the bidder is unable to know the owner's price for time. Mississippi must have anticipated this argument by establishing the value of time for each contract. Yet Marsh insists that to obtain truly competitive prices for time, the owner should include it as an alternative bid item carefully controlled by the language in the request for bids. Thus, the Mississippi DOT system remains valid by avoiding the problems Marsh warns about. 

Figure 7

\section{Relationship Between Project Duration and Quality}

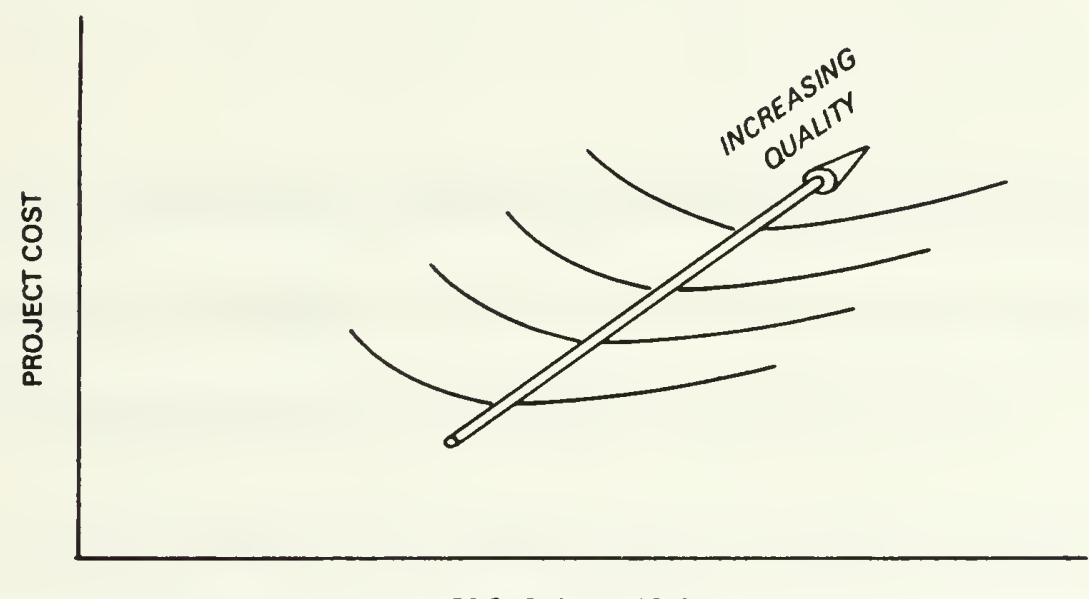

PROJECT DURATION

Reproduced from "Managing the Engineering and Construction of Small Projects" by Richard E. Westney. 



\subsection{City Governments}

Another layer of public owners responsible for construction contracts are local city public works departments. These city departments are responsible for all aspects of their facility needs similar to the federal and state governments.

The city of Gainesville, Florida was selected as a typical small city for the purposes of investigating their method of determining contract durations. The method the city uses divides projects up into two categories, small and large. For small projects, the city estimates the contract duration by utilizing their observed production rates of their own workers on such items as street repair, sidewalk improvements and the like. The rates are then applied to a quantity takeoff to yield a rough approximation of the duration. This number is then modified to take into account such factors as site restrictions, urgency of need, complication of work, and amount of traffic control required to complete the project. This duration is then set as the maximum in the contract documents. Bidders are invited to bid both time and money. ${ }^{29}$ This allows the city to take advantage of the contractors increased productivity without having to pay 

a premium for exclusivity of his assets. For larger projects which would include projects vertical in nature, the city relies on the recommendation of the design firm.

\subsection{Design Firms}

Most public owners rely on outside expertise to accomplish their design requirements. Architect/engineer firms have for years made various recommendations to their clients concerning all aspects of the proposed project. For the contract duration, most design firms interviewed relied on their experience with similar projects. In addition to the designer's experience, the duration is adjusted for the size of the job as measured in estimated construction costs, any long lead materials such as electrical transformers, air conditioning units, and special computer equipment, and complexity of the overall project. ${ }^{30}$ Other design firms interviewed also consider those same items and additionally place emphasis on the type of project such as new construction or renovation, and if a different delivery method is being utilized such as CM. ${ }^{31}$ 

Based on the information presented by designers, the three most critical factors in determining a contract duration are the type of project, the size of the project, and any long lead equipment. All of these factors are combined in to the designer's experience. Thus, the final recommendation from the designer is based on his previous experience.

In Chapter Five, some thoughts on designer's experience and contract durations will be expressed. 



\section{CHAPTER FIVE SOME THOUGHTS ON CONTRACT DURATIONS}

\subsection{Why No Analysis?}

The question of why owners do not demand contract durations that are closer to the optimum are due to a variety of reasons. One is that the cost of performing an intensive evaluation of the factors that effect the duration and putting together all the information into a duration is viewed as not cost effective. This type of analysis will take time also that could probably be more beneficial to the owner. Also the number of days that could be eliminated from the contract are probably not that high. For federal agencies, it just does not make economic sense to investigate for a week and determine that a 500 day contract could be 10 to 15 days shorter and be at its optimum duration. One has to consider that the user has probably waited as much as five years for the facility and an extra two weeks is not likely to cause any additional harm. Yet there are contracts where saving an extra two weeks would be worth the extra cost 
for the analysis. Therefore, each public owner should examine his proposed contracts and identify those which additional analysis of the contract duration is worthwhile. The savings in terms of dollars may only be small, however, if the agency can deliver a significant project "on time", then some embarrassment can be spared.

\subsection{Too Many Factors}

Chapter Two discusses several factors which affected the contract duration. The owner is faced with a myriad of choices when he starts a construction project. Though he is anxious to complete the facility as soon as possible, he is often overwhelmed by the complexity of all the decisions that go into it. Public owners often solve this by having professional designers make most of the choices for them. The public owner will often have a clear concept of what he needs in terms of the facility, but the design will rightfully be handled by the professional architect or engineer. Herewith, the architect or engineer firm makes the initial suggestion of the contract duration. Thus, it is not until the project is almost completely designed, that the contract duration is 

determined. The owner often starts with a target date in mind, say a particular month to have the facility ready. A target date within that month will be set and the design, review, bidding, and construction period are backed away from that date to the present. Since the design, review, and bidding occur before the construction, these items can (and often do) consume more than the time allotted to them. This creates a problem when the owner expects his project to be completed by the target date. The user will often make plans to use the facility based on that date. When the design, review, bidding, and award consume more time than allotted, the construction period is likely to be shortened causing an increase in contract price so that the user will have the facility by the "promised" date.

The effects of this compression are that the contractor is likely to escalate his bid for the premium work he is required to perform. Since there are always problems which occur, it is possible that the contractor will be unable to complete the project on the "promised date". Many of the problems will not be the contractor's fault. The owner may have needed 
changes to make to the facility which effected contract duration. As can be seen, there is a potential for many unknown quantities that must be estimated accurately in order to predict the completion of the facility.

\subsection{Measurement of Success}

It is difficult to measure success of a contract duration. This is true because construction contracts will be changed. As stated earlier, it is almost a universal fact that the contract completion date will be extended. Because of this fact, it is difficult for the designer to know if he chose the optimum duration. Additionally, because changes almost always occur, the designer is left with experience that is bloated with delays. This compromises his ability to evaluate the project clearly and determine an optimum duration. By contrast, most contractors find the durations either adequate or too short. ${ }^{33}$ This was the opinions offered by several designers interviewed during this research. It is not surprising that designers were told by contractors that the durations were either adequate or too short. This attitude by contractors reinforces their ability to spread their resources thinly over several projects to maximize 

their profits. Public owners have become accustomed to this attitude because of their fear of higher bids. Owners are aware that if they buy the exclusivity of the contractor, they will be paying a premium. That fear, and the desire to achieve a competitive market, forces owners to accept the current uncertain conditions of contract durations.

\subsection{Euture Contracts}

Public owners have a right to a competitive market for their contracts. They deserve a fair and reasonable delivery time for a fair and reasonable price. Instinctively, public owners should be striving for the optimum price versus time combination for all their contracts. The fact that it is not done is underscored by the fact that most people involved in the contract duration decision were not aware of an optimum duration even existing.

One possible path to correct this deficiency is to continue a program that the Navy engineering field divisions already have in place. Most of the EFDs have been assigned as the lead manager for a specific type of facility 

such as airplane hangers, hospitals and the like. Most naval facilities are repetitive in nature, since most bases have the same core of requirements such as administrative, health care, repair, warehouse, and storage facilities. The Naval Facilities Engineering Command has recognized this and established a lead EFD for selected facilities types. These lead EFDs are currently tasked with design development of prototype modular facilities. This program is designed to develop the kind of modular designs that can be adapted to all locations and require minimum modifications to be a successful, complete design. With that, the EFD could be tasked to further analyze their lead facility for the optimum contract duration. A series of modifiers could also be developed to help correct the contract duration for the adjustments to a different location. These modifiers could take into account such factors as local changes in weather, site limitations, administrative requirements for the base, and local labor practices. 


\section{CHAPTER SIX \\ SUMMARY AND CONCLUSIONS}

\subsection{Summary}

Three significant points are evident from this study of contract durations. First, there exists an optimum duration for the cost unique to each contract. This optimum duration takes into account all the factors covered in Chapter Two. This duration will also represent the most likely time for actual completion of the project. When an owner makes a contract for a facility, he strives to balance many different things such as cost, quality, function, and time. In order to balance the time considered necessary for the construction with his time available, the owner will make a choice about the importance of the optimum duration. As shown in figure 1, either side of the optimum duration costs the owner money.

Secondly, owners often rely on designers and their own experience for the recommendation of contract duration. Designers utilize their 

experience with similar projects to predict the contract duration. This deprives the owners of a chance to utilize the optimum duration for the contract because no independent evaluation of the contract has been performed.

Thirdly, there is really only one delivery date worth having, the one that can realistically be kept. Yet due to a myriad of problems and procedures, this date is rarely obtained. The reasons for this come from all members of the construction team, owner, designer, and contractor. The designer makes recommendations based on his experience with similar projects. He is, by nature, conservative in his approach. The owner derives his experience from designers. Contractors are rarely knowledgeable about their productivity. ${ }^{32}$ Thus, no one really knows or strives for the productivity that is available from the contractor. Without that knowledge, there can not be a realistic appraisal of the contract duration. Thus the factors which influence the contract duration are not analyzed. 



\subsection{Conclusions}

Considering the rising cost of construction, and the demand by public owners to achieve the best facility for the price, this is an idea whose importance will grow. By implementing a program where the optimum contract duration is sought out, the actual delivery of facilities will be more realistically reflected. In any event, a public owner who utilizes a method that strives for the optimum will have a better understanding of the time required for delivery of their facility.

Finally, contract durations are important to everyone. The optimum duration represents the best possible expenditure of time and money for a project, hopefully designed to benefit it's recipients. Public owners have the right to demand the optimum duration for the contract before the project is awarded. Through education of owners and more research, quantitative methods may be developed to predict the optimum contract duration. Armed with the optimum contract duration, owners will be able to make more intelligent choices when awarding contracts. 



\section{Endnotes}

1. Westney, Richard E., Managing The Engineering and Construction of Small Projects. Marcel Drukker, Inc. New York, 1985, p 16.

2. Clough, Richard H., Construction Contracting, $5^{\text {th }}$ edition, John Wiley \& Sons, Inc, New York, 1986, pp 7.

3. $\underline{\text { lbid., }} \mathrm{pp} 7-8$.

4. $\quad$ lbid., $p 7$.

5. Interview with Mr. John Ott, Lincoln Property Company, commerical developers, Tampa, Florida, 10 November, 1987.

6. Clough, ㅇ. Cit. p 7 .

7. lbid, $p 7$.

8. Herbsman, Zohar, A Technique for Scheduling Linear Projects in Civil Engineering, unpublished manuscript, 1987.

9. Metal Buildings Manufacturers Association, "Fact Book", 1986, p 3.

10. Smith,Stephen E, and Woodrow W. Wilson, William C. Burns, and Robert A. Rubin, "Contractual Relationships in Construction", Journal of the Construction Division. Proceedings of the American Society of Civil Engineers, Vol 93, December 1975, p 911.

11. Westney, Op. Cit. p 55.

12. The Business Roundtable, Contractual Arrangements, A Construction Industry Cost Effectiveness Project Report, Report A-7, October 1982, p 8.

13. lbid, $p 8$. 

14. Ibid. $\mathrm{p} 8$.

15. Clough, Op. Cit. p 140.

16. Ibid, p145.

17. The Business Roundtable, Op. Cit. p 13.

18. Brockian, Davis A., An Analysis of Primary Project Delivery Methods, Report for the Degree Master of Building Construction, Department of Building Construction, University of Florida, Gainesville, Florida, December, 1985, p 19.

19. lbid. p 19.

20. General Services Administration, The PBS Building Systems Program and Performance Specification for Office Buildings, November 1975, p B-19.

21. Clough, Op. Cit. p 15.

22. U. S. Navy, Naval Facilities Engineering Command, P-68 Contracting Manual, February 1985, p 4-2.10.

23. $\quad \underline{\text { bid. }}, \mathrm{p} 4.2 .1$

24. Telephone interview with Mr. Dennis Blackwell, Naval Facilites Engineering Command, Southern Division, Charleston, South Carolina, 28 October, 1987.

25. U.S. Army Corps of Engineers Regulation ER 1-1-11, "Network Analysis System" dated 15 October 1985, p 2.

26. Telephone interview with Mr. Joe Whetstone, Chief Estimating Branch, Jacksonville District, U.S. Army Corps of Engineers, 24 February, 1988.

27. Ibid. 

28. Westney, Op. Cit. p 20.

29. Telephone interview with Ms. Sharon Oakes, Engineering Division Supervisor, City of Gainesville, Florida, Public Works Department, 17 February, 1988.

30. Telephone interview with Mr. William Jackson, owner, Jackson-Reeger, Architects, Incorporated, Gainesville, Florida, 17 February, 1988.

31. Telephone interview with Mr. Dave Goodwin, member, Craig Salley and Associates, Architects, Gainesville, Florida, 17 February, 1988.

32. Flannegan, Michael, S., Estimation of Production Rates in Heavy Construction, Report for the degree Master of Engineering, Department of Civil Engineering, University of Florida, Gainesville, Florida, December, 1987, p 55.

33. Jackson, Op.Cit. 

Acret, James, Attorney's Guide to California Construction Contracts and Disputes, California Continuing Education of the Bar, Berkeley, California, 1976.

Barrie, Donald S., and Paulson Boyd C. jr, Professional Construction Management, $2^{\text {nd }}$ edition, $M^{C}$ Graw-Hill Book Co, New York, 1979.

Bockian, David, A. An Analysis of the Primary Project Delivery Methods. Report for the degree Master of Building Construction, Department of Building Construction, University of Florida, Gainesville, Florida, Fall 1985.

Callahan, Michael T., and H. Murray Hohns, Construction Schedules, The Michie Company, Charlottesville, Va, 1983.

Clough, Richard H. Construction Contracting. $5^{\text {th }}$ edition, John Wiley and Sons, New York, 1986.

"Contractual Arrangements", A Construction Industry Cost

Effectiveness Project Report. The Business Roundtable, Report A-7, October 1982.

Fields, Ronald, An overview of Various Contractual Relationships in the Construction Industry, Report for the degree Master of Engineering, Department of Civil Engineering, University of Florida, Gainesville, Florida, May 1978.

Flannegan, Michael S., Estimation of Production Rates in Heavy Construction, Report for the degree Master of Engineering, Department of Civil Engineering, University of Florida, Gainesville, Florida, December, 1987.

Fisk, Edward R., Construction Project Administration, John Wiley \& Sons, New York, 1978. 
Goheen, Michael, Conceptual Estimating for the General Contractor Report for the degree Master of Building Construction, Department of Building Construction, University of Florida, Gainesville, Florida, August, 1974.

Hancher, Donn E, and James E. Rowings, "Setting Highway Construction Contract Durations", Journal of the Construction Division, Proceedings of the ASCE, June 1981, pgs $169-179$.

Harris, Robert B., Precedence and Arrow Networking Techniques for Construction, John Wiley and Sons, New York, 1968.

Havf, Harold D. Building Contracts for Design and Construction, John Wiley and Sons, New York, 1968.

Herbsman, Zohar, A Technique for Scheduling Linear Projects in Civil Engineering, unpublished manuscript.

Herbsman, Zohar, and William Coons, "Study of Scheduling Techniques for FDOT Construction Projects, University of Florida, Department of Civil Engineering EIES, October 1986.

General Services Administration, Ihe PBS Building Systems Performance Specifications for Office Buildings, $3^{\text {rd }}$ Edition, Government Printing Office, Washington, D.C., 1975.

Interview with Mr. Dennis Blackwell, Naval Facilities Engineering Command, Southern Division, Charleston, S. C., 28 Oct 1987.

Interview with Mr. Dave Goodwin, member, Craig Salley and Associates, Architects, Gaineville, Florida, 17 February, 1988.

Interview with Mr. William Jackson, principal, Jackson-Reeger, Architects, Gainesville, Florida, 05 February 1988.

Interview with Mr. Kenneth $\mathrm{M}^{\mathrm{C}} \mathrm{Gurn}$, President, McGurn Investments, commerical developer and contractor, Gainesville, Florida, 7 October 1987. 

Interview with Mr. Robert H, Miller \& Associates, consulting engineers, Fort Lauderdale, Florida, 29 Sep 1987

Interview with Ms. Sharon Oakes, Engineering Division Supervisor, City of Gainesville, Florida, Department of Public Works, 17 February 1988.

Interview with Mr. John Ott, Lincoln Properties Inc, commercial developers, Tampa, Florida,10 Nov 1987.

Interview with Mr. John Tindell, principal, Eugene R. Davis, Architects and Developers, Gainesville, Florida, 17 February, 1988.

Interview with Mr. Joe Whetstone, Chief Estimating Branch, Jacksonville District, U. S. Army Corps of Engineers, 24 February 1988.

Jellinger, Thomas C., Construction Contract Documents and Specifications, Addison, Wesley Publishing Co., Reading, Mass, 1981.

Marsh, P.D.V., Contracting For Engineering and Construction Projects. Gower Press, London, 1969.

Metal Building Manufacturers Association, MBMA "Fact Book", 1986.

Ruehe, John H., Construction Management. A Study of A New Project Delivery System, Report for the degree Master of Engineering to the Department of Civil Engineering, University of Florida, Gainesville, Florida, Fall 1987.

Simon, Michael S., Construction Contracts and Claims. $M^{C}$ Graw-Hill, Book Co., New York, 1979.

Smith, Stephen E, Woodrow W. Wilson, William C. Burns, and Robert A. Rubin, "Contactual Relationships in Construction", Jeurnal of the Construction Division. Proceedings of the American Society of Civil Engineers, Vol 93, December 1975. 

Sweet, Justin, Legal Aspects of Architecture, Engineering, and the Construction Process, $3^{\text {rd }}$ edition, West Publishing Co., St. Paul, Mn., 1985.

U. S. Army, Corps of Engineers Regulation ER 1-1-11, "Network Analysis System", dated 15 October 1985.

United States Code of Federal Regulations, Title 48, Chapter 1, Federal Acquisition Regulations System, U. S. Government Printing Office, Washington, D. C., 1986.

U. S. Naval Facilities Engineering Command, Contracting Manual. NAVFAC P-68, Naval Publications and Forms, Philadelphia, Pa, 1985.

Westney, Richard, E. Managing The Engineering and Construction of Small Projects, Marcel Dekker, Inc, New York, 1985.

Willenback, Jack, H., and H. Randolph Thomas, Planning. Engineering. and Construction of Electric Power Generation Facilities, John Wiley \& Sons, Inc. New York, 1980. 





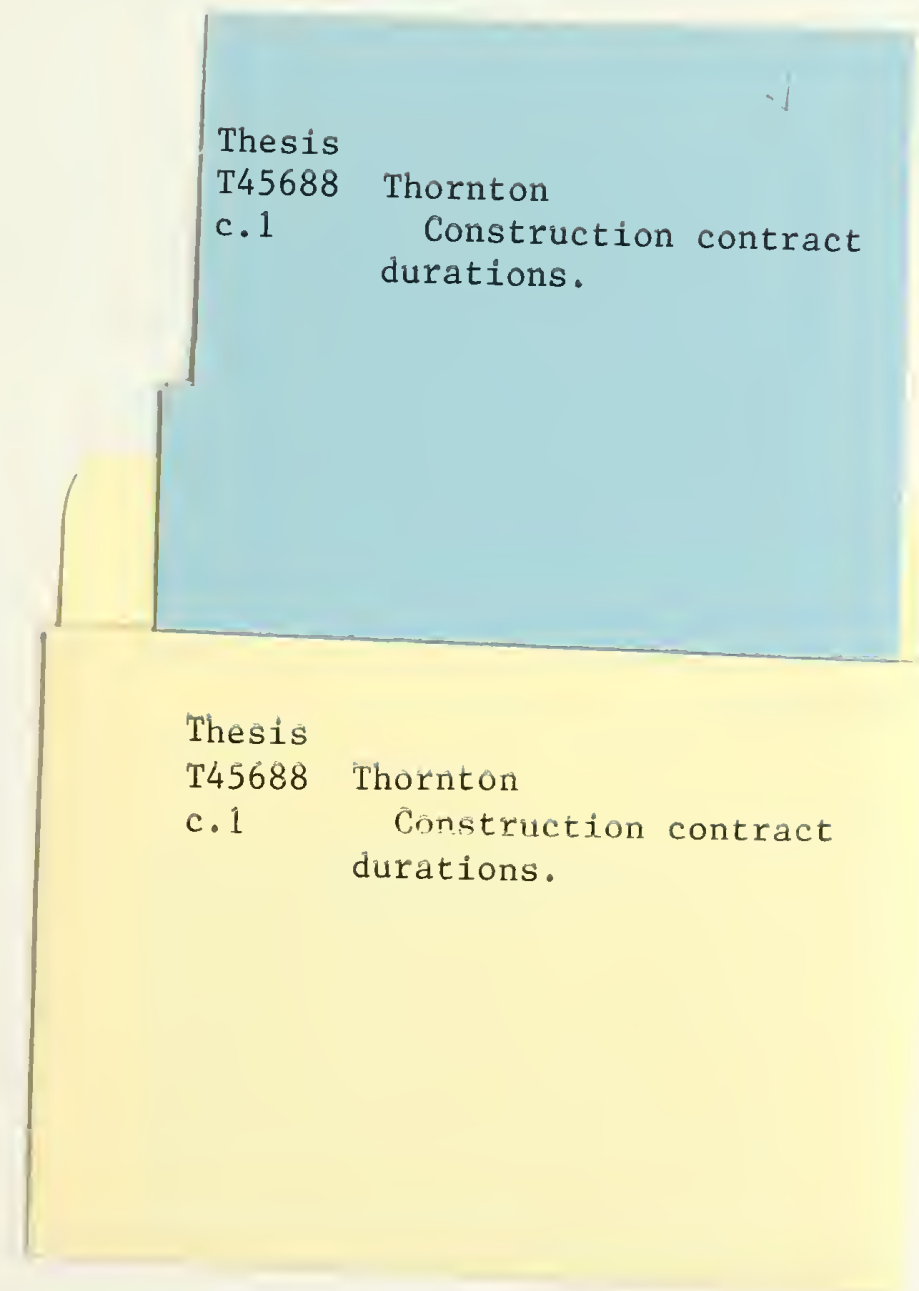


